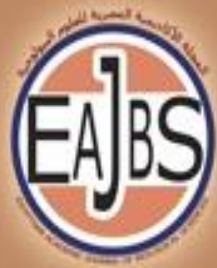

EGYPTIAN ACADEMIC JOURNAL OF
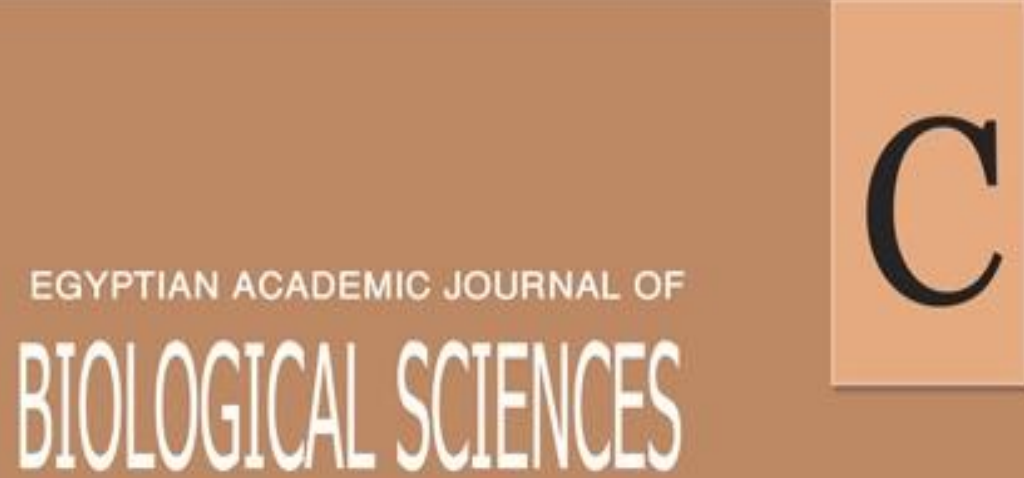

PHYSIOLOGY \& MOLECULARBIOLOGY
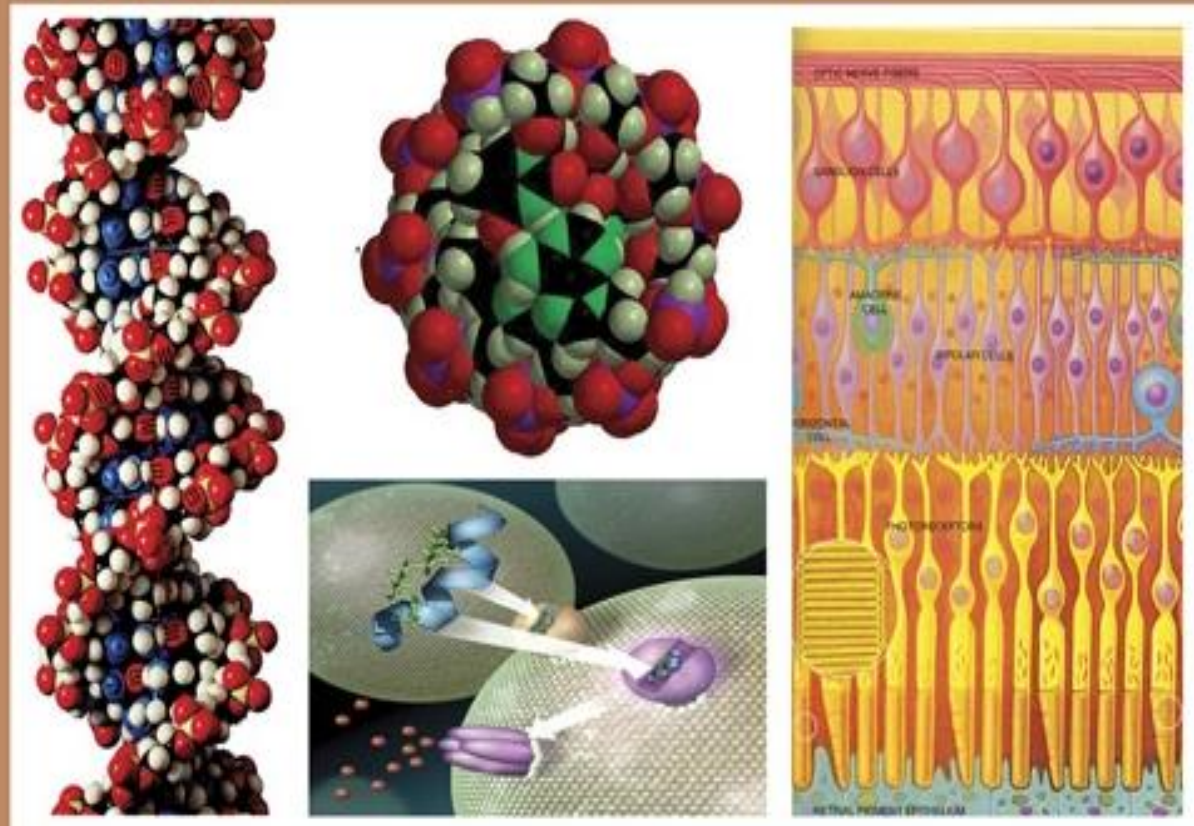

ISSN

2090-0767

WWW.EAJBS.EG.NET

Vol. 13 No. 2 (2021) 
Egypt. Acad. J. Biolog. Sci., 13(2):155-176 (2021)

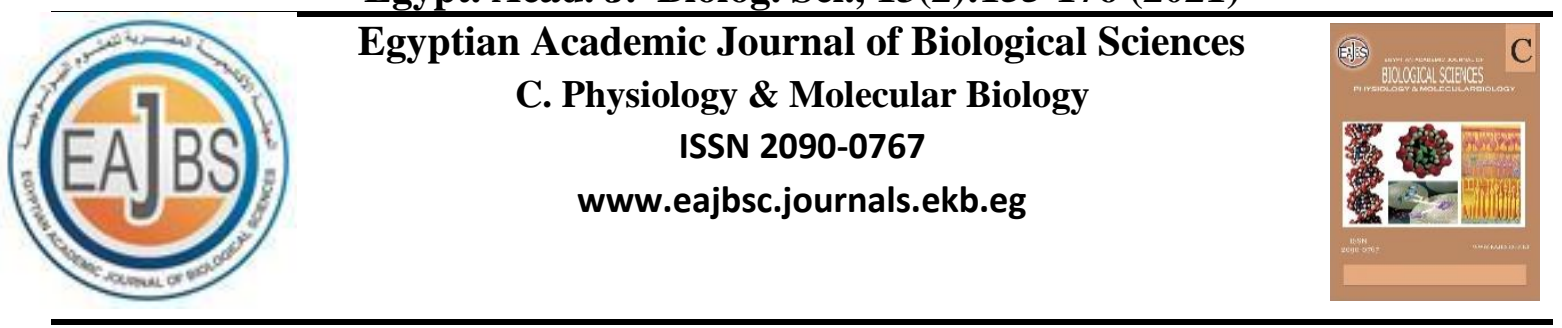

\title{
Toxicity Induced by Indoxacarb Exposure in Male Albino Rats and The Possible Protective Effects of Vitamin $\mathrm{C}$ and Zinc
}

\author{
Hanaa F. Hassan ${ }^{1 *}$; Nisreen. D. M. Toni ${ }^{2}$ and Noha M. Meligi ${ }^{1}$ \\ 1- Zoology Department, Faculty of Science, Minia University 61519, Minia, Egypt \\ 2-Pathology Department, Faculty of Medicine, Minia University 61519, Minia, Egypt \\ *E. Mail : hanaafawzy78@mu.edu.eg - Nisreen_dahi@yahoo.com \\ noha.melege@mu.edu.eg
}

\section{ARTICLE INFO}

\section{Article History}

Received:30/9/2021

Accepted:7/11/2021

\section{Keywords:}

Albino rats;

Biochemical

parameters;

Indoxacarb;

Vitamin C; Zinc.

\section{ABSTRACT}

Accidental exposure or overexposure to pesticides can have considerable consequences. A pesticide poisoning happens after chemicals proposed to control a pest affect non-target organisms such as humans. The present work aimed to evaluate the potential adverse effects of the insecticide, indoxacarb, and the protective effects of supplementation with vitamin C (200 mg/kg), and zinc $(\mathrm{Zn})(100 \mathrm{mg} / \mathrm{kg})$ (separately or together) on the resulted toxicity. Thirty male SpragueDawley rats were randomly divided into five groups $(n=6)$ : group I served as the control group, group II received orally a sublethal dose of indoxacarb $(100 \mathrm{mg} / \mathrm{kg})$, group III received orally indoxacarb+vitamin $\mathrm{C}$, group IV received orally indoxacarb $+\mathrm{Zn}$ and group $\mathrm{V}$ received orally indoxacarb+vitamin $\mathrm{C}+\mathrm{Zn}$, three times a week for 21 days. Exposure of rats to indoxacarb caused significant changes of some oxidative stress parameters (lipid peroxide (LPx) level, superoxide dismutase (SOD) and glutathione peroxidase (GPx) enzyme activity) besides a substantial increase in the activities of hepatic enzymes (aspartate aminotransferase (AST) and alanine aminotransferase (ALT). In addition, high-density lipoprotein cholesterol (HDL-C), low-density lipoprotein cholesterol (LDL-C), total protein, albumin, and kidney functions (levels of creatinine, urea, uric acid, and aldosterone hormone activity) in indoxacarb-treated rats exhibited remarkable changes compared with the control rats. Also, the histological changes in the liver and kidney of all groups were investigated. Furthermore, the mixture of vitamin $\mathrm{C}$ and zinc ameliorated the biochemical parameters and the histological changes in the liver and kidney of indoxacarb-treated rats. In conclusion, the mixture of vitamin $\mathrm{C}$ and $\mathrm{Zn}$ may display beneficial effects against indoxcarb-toxicity through improvement in the examined biochemical parameters imbalance and histological alterations in liver and kidney over the use of either of them alone.

\section{INTRODUCTION}

Different groups of pesticides have harmful effects on habitats and are not limited to an ecological niche but often disturb human health through the accumulation of toxic residues in the food chain (Sandeep et al., 2016). 
Indoxacarb is a non-systemic insecticide that is used to control sucking and chewing insects and was found to be more effective in lepidopteran pests of rice, pears, apples, cotton, and fruiting vegetables. Indoxacarb has shown good effectiveness in the control of bees, cockroaches, fleas, termites, and houseflies. This insecticidal action occurs by blocking the channels of sodium in the target pest nervous system and communication routes leading to impaired nerve function, paralysis, stoppage of feeding and even death (US EPA, 2000).

Pesticides cause oxidative stress because of an increase in reactive oxygen species (ROS), a disturbance of antioxidant defense systems, or an inadequate capability to restore oxidative injury. Potential damage induced by oxidative stress exerts alterations of cellular membrane lipids, proteins, and DNA. Previous studies have reported that indoxacarb induces oxidative stress in different organs like the kidney, testes, and ovary and induces changes in biochemical constituents of the liver in albino mice (Mudaraddi et al., 2012). Moreover, mice that have been treated with many doses of indoxacarb for 30 days showed distinguished adverse effects on protein and lipid contents and some antioxidant enzyme activities as catalase and superoxide dismutase (Abdelrasoul, 2018).

Vitamin C (VC) shows structural similarity to glucose and can be considered as its alternative in many chemical processes. The anticarcinogenic and antimutagenic roles of $\mathrm{VC}$ have been explored in a range of in vivo and in vitro systems subjected to pesticides (Durak et al., 2009). VC is an influential antioxidant; it readily scavenges ROS such as superoxide, hydroxyl, and aqueous peroxyl radicals. Moreover, it collaborates with Vitamin $\mathrm{E}$ in membranes and lipoproteins to redevelop $\alpha$-tocopherol from $\alpha$ tocopherol radicles (Kojo, 2004). Subjected to certain conditions, VC can avert the vulnerability of lower respiratory tract infection (Hemila, 1997). Recently, it was demonstrated that a moderate amount of VC supplementation can be utilized as a possible route to prevent COVID-19, as it may lead to lower respiratory tract infection (Matthay et al., 2020 and Wang et al., 2020).

Zinc $(\mathrm{Zn})$ is a trace element that is important for the standard growing and the growth of all animal species and is vital for the integrity of the immune system. The lack of $\mathrm{Zn}$ results in a reduction in the growth rate (Prasad et al., 1996). $\mathrm{Zn}$ is vital for enzymes involved in DNA synthesis, mitosis, and protein synthesis (Bettger and O'Dell, 1993). Moreover, it shows ameliorative effects against oxidative liver damage induced by organophosphate intoxication (Goel et al., 2005). Recently, Zhang and Liu (2020), reported that $\mathrm{Zn}$ supplement showed a potential efficacy on symptoms related to COVID-19 such as diarrhea and lower respiratory tract infection, as well as on the new COVID-19 coronavirus itself.

Some studies have been attempted to evaluate the amelioration role of $\mathrm{VC}$ and $\mathrm{Zn}$ on some biochemical alterations induced by insecticides such as chlorpyrifos (Uchendu et al., 2012). However, to the best of our knowledge, there are no studies on indoxacarb with respect to co-administration with $\mathrm{VC}$ and $\mathrm{Zn}$. Hence, the main objective of our investigation is to assess the degree of hazard posed by the exposure to a sublethal dose of indoxacarb on the antioxidant enzymes and hepatic and renal function in male albino rats. Furthermore, the present study evaluates the efficiency of $\mathrm{VC}$ and $\mathrm{Zn}$ in amending the damage produced by the examined insecticide. In addition, due to the documented synergistic activities between vitamins $\mathrm{E}$ and C (Hamilton et al., 2000), vitamin E and $\mathrm{Zn}$ (Zago and Oteiza, 2001), a significant query arose whether or not a mixture of $\mathrm{VC}$ and $\mathrm{Zn}$ would provide 
better protection against toxicity to indoxacarb.

\section{MATERIALS AND METHODS Animal Ethics:}

The authors declare that all experimentation, transportation, and care of the animals used in this study were carried out in compliance with the approval of the Faculty of Science, Minia University's policy on animal use and ethics. All mandatory laboratory health and safety measures have been adhered to while performing the experimental work of this study.

\section{Experimental Animals:}

Thirty adult male albino rats (Sprague-Dawley) were collected from the research laboratory's animal house in Egypt at the age of 6-8 weeks, weighing 150-200 g. The rats were housed in a wellventilated room at $25 \pm 3^{\circ} \mathrm{C}$ in clean plastic cages for 3 weeks before the commencement of the experiment as an acclimatization period. Animals had access to ordinary food and water $a d$ libitum.

\section{Chemicals:}

Indoxacarb is an oxadiazine pesticide (Fig. 1). its IUPAC (International Union of Pure and Applied Chemistry) name is methyl (4aS)-7-chloro-2[methoxycarbonyl-[4-

(trifluoromethoxy)phenyl]carbamoyl]-3,5dihydroindeno[1,2-e] $[1,3,4]$ oxadiazine- $4 a$ carboxylate. Indoxacarb was supplied from the Agrimatco Business (Minia, Egypt). The sublethal dose of indoxacarb $(100 \mathrm{mg} / \mathrm{kg}$ body weight in $1.0 \mathrm{ml}$ corn oil) was received orally, three times a week for 21 days. Vitamin C (200 mg/kg) and $\mathrm{Zn}(100 \mathrm{mg} / \mathrm{kg})$ were bought from local pharmacy.

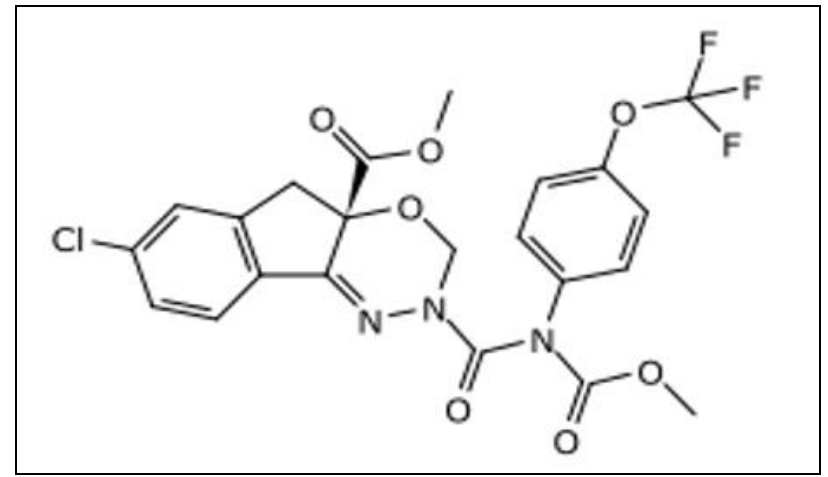

Fig. 1: General chemical structure of indoxacarb.

\section{Experimental Design:}

The rats were divided into five classes $(n=6)$ as follows:

group 1 (control group) received orally 1.0 $\mathrm{ml}$ of corn oil, group 2 (indoxacarb-treated group) received orally indoxacarb (100 $\mathrm{mg} / \mathrm{kg}$ body weight in $1.0 \mathrm{ml}$ corn oil), group 3 (indoxacarb + VC- treated group) received orally a mixture of indoxacarb $(100 \mathrm{mg} / \mathrm{kg}$ body weight in $1.0 \mathrm{ml}$ corn oil $)+\mathrm{VC}(200 \mathrm{mg} / \mathrm{kg})$, group 4 (indoxacarb $+\mathrm{Zn}$ - treated group) received a mixture of indoxacarb $(100 \mathrm{mg} / \mathrm{kg}$ body weight in $1.0 \mathrm{ml}$ corn oil $)+\mathrm{Zn} \mathrm{(100}$ $\mathrm{mg} / \mathrm{kg}$ ), group 5 (indoxacarb $+\mathrm{VC}+\mathrm{Zn}$ treated group) received a mixture of indoxacarb $(100 \mathrm{mg} / \mathrm{kg}$ body weight in 1.0 $\mathrm{ml}$ corn oil $)+\mathrm{VC}(200 \mathrm{mg} / \mathrm{kg})+\mathrm{Zn}(100$ $\mathrm{mg} / \mathrm{kg}$ ). All doses were given orally using a stainless-steal stomach tube three times per week for 21 consecutive days. Observation on animals was performed daily to record any sign of toxicity.

\section{Recording of Body Weights:}

At the start of the experiment and prior to dissection, rats were weighed to estimate the changes in the body weight.

\section{Blood Sampling:}

After 21 days, the animals were fasted overnight and then killed by cervical decapitation to collect the samples of blood. Blood samples collected on 
ethylenediaminetetraacetic acid (EDTA) were used to separate plasma after centrifugation at $4000 \mathrm{rpm}$ for $10 \mathrm{~min}$. Other blood samples were left to coagulate at room temperature and centrifuged as described above to separate serum samples. For biochemical analysis, all samples were kept frozen at $-80{ }^{\circ} \mathrm{C}$.

\section{Estimation of Biochemical Analysis:}

Assays of both plasma and serum biochemicals were calorimetrically calculated using the commercial diagnostic kits. Plasma lipid peroxide (LPx) level and glutathione peroxidase (GPx) activity were measured according to the methods of Ohkawa et al. (1979) and Paglia and Valentine (1967) respectively. The activity of the plasma superoxide dismutase (SOD) was determined according to the method of Marklund and Marklund (1974). Determination of Serum aspartate aminotransferase (AST) and alanine aminotransferase (ALT) activities was assessed using the method of Bergmeyer $e t$ al. (1986). Based on the methodology adopted by Badimon et al. (1990), serum high-density lipoprotein cholesterol (HDLC) and low-density lipoprotein cholesterol (LDL-C) rates were assessed. Serum total protein and albumin levels were measured according to the methods reported by Leonard et al. (1971) and Young and Friedman (2001), respectively. Serum creatinine, urea and uric acid levels were determined according to the methods of Young and Friedman (2001), Patton and Crouch (1977) and Doumas et al. (1981) respectively. Plasma aldosterone hormone activity was measured using the method of Cartledge and Lawson (2000).

\section{Histopathological Evaluation:}

Histopathological examination of the liver and kidneys of the studied rats was done to assess the structural abnormalities and to correlate them to the biochemical findings. Multiple tissue sections were taken and fixed in 10\% formaldehyde and embedded in paraffin blocks. Multiple $4 \mu \mathrm{m}$ sections were stained with Hematoxylin and Eosin
(H\&E) stain following the standard protocol. Sections were examined under a light microscope by a pathologist who was blind to the data of the groups. Images were taken by a digital camera (Nikon) connected to a light microscope (Olympus, Japan). Signs of liver injury are fatty change, cellular necrosis, hemorrhage, congestion, and inflammatory cells infiltration. Signs of renal injury are alteration of the architecture of the cortex and medulla and the glomerular structure in addition to both proximal and distal tubules.

\section{Immunohistochemical Assessment of iNOS:}

Deparaffinization then tissue rehydration was done by using xylene and descending grades of ethyl alcohol respectively for $10 \mathrm{~min}$ each. Blocking of peroxidase activity was done using hydrogen peroxide in methanol solution for $30 \mathrm{~min}$. Antigen retrieval using citrate buffer ( $\mathrm{pH}$ 6) was done. Samples were incubated with goat serum for $5 \mathrm{~min}$ followed by overnight incubation of samples at $4{ }^{\circ} \mathrm{C}$ with an anti-iNOS polyclonal antibody. Incubation was done with secondary antibody for $10 \mathrm{~min}$ then with streptavidin-peroxidase for $5 \mathrm{~min}$. Incubation was done with $\mathrm{DAB}$ for $3 \mathrm{~min}$. Counterstaining of the slides using Meyer's haematoxylin was done. Dehydration in ascending grades of alcohol followed by clearance, mounting and finally covering with coverslips was done. With each run, both positive and negative controls were processed. Immunostaining was scored semiquantitatively based on the assessment of both intensities of staining and the percentage of cells that stained positively. The staining score was calculated by multiplying the percentage of positive cells by staining intensity. The intensity of staining was classified as 0 (negative), $1+$ (weak), $2+$ (moderate) or $3+$ (strong). The final score ranged from 0 to 300 . Negative control slides were treated with PBS 
instead of using the iNOS (Ali et al., 2018).

\section{Statistical Analysis:}

The findings of the present analysis have been evaluated using statistical package of social sciences (SPSS) statistics software for Windows, Version 22 (IBM crop., Armonk, NY, USA). The significance among groups was evaluated by one-way analysis of variance (ANOVA), accompanied by Tukey's multiple comparison test. The data were expressed as the mean \pm standard deviation, where $\mathrm{P}<0.05$ was measured as the degree of significance. Graphs were plotted with Excel MS Office version 2016.

\section{RESULTS \\ Toxicity signs and mortality}

Throughout the study period, some treated rats with indoxacarb as represented in group 2 and its mix with $\mathrm{VC}$ and $\mathrm{Zn}$ as represented in groups 3 and 4, respectively, showed signs of toxicity such as circling, convulsions, weakness and muscle spasms in hind legs. In addition, the above groups reported a gradual decline in body weight. No death has been documented in all the experimental groups.

\section{Evaluation of biochemical parameters}

As shown in (Table 1), LPx level (Fig. 2) and SOD activity (Fig. 3) increased significantly after treatment with indoxacarb. However, GPx activity (Fig.
3) was decreased significantly in indoxacarb -treated group compared to the control group. These effects were recovered to a large extent by treatment with $\mathrm{VC}+\mathrm{Zn}$ where there were significant changes in LPx level, GPx and SOD activation when compared to the indoxacarb-treated group. As shown in (Table 2), a substantial increase in liver enzyme activities (AST, ALT) (Fig. 4) and LDL-C levels (Fig. 5) and a significant decrease in total protein, albumin (Fig. 6) and HDL-C levels (Fig. 5) of rats treated with indoxacarb relative to control rats, demonstrating the incidence of hepatic toxicity. As indicated in the table (3), a significant rise in renal functions (creatinine, urea, and uric acid levels (Fig. 7) and aldosterone hormone activity (Fig. 8)) in an indoxacarb-treated group compared to the control group. While for rats treated with indoxacarb $+\mathrm{VC}$ and indoxacarb $+\mathrm{Zn}$, there was a slight improvement of most of the tested biochemical parameters when compared to the indoxacarb-treated group. However, the administration of $\mathrm{VC}+\mathrm{Zn}$ combined with indoxacarb amended the utmost of these parameters. We observed that the mixture of $\mathrm{VC}+\mathrm{Zn}$ modulated significantly $(\mathrm{P}<0.05)$ all changes in biochemical parameters in indoxacarbtreated rats and returned approximately the values to the control values.

Table 1: Plasma LPx level and GPx and SOD enzyme activity in control and experimental rats.

\begin{tabular}{|l|l|l|l|l|l|}
\hline \multicolumn{1}{|c|}{ Groups } & Control group & $\begin{array}{c}\text { Indoxacarb- } \\
\text { treated group }\end{array}$ & $\begin{array}{c}\text { Indoxacarb } \\
\text { +VC treated } \\
\text { group }\end{array}$ & $\begin{array}{c}\text { Indoxacarb+Zn } \\
\text { treared group }\end{array}$ & $\begin{array}{c}\text { Indoxacarb } \\
\text { +VC+Zn treated } \\
\text { group }\end{array}$ \\
\hline $\mathrm{LPx}(\mathrm{nmol} / \mathrm{ml})$ & $4.44 \pm 0.11$ & $12.00 \pm 0.91^{\mathrm{a}}$ & $7.67 \pm 0.31^{\mathrm{a}}$ & $7.67 \pm 0.31^{\mathrm{a}}$ & $7.67 \pm 0.31^{\mathrm{a}}$ \\
\hline $\mathrm{GPx}(\mathrm{U} / \mathrm{L})$ & $443.60 \pm 4.15$ & $210.80 \pm 1.82^{\mathrm{a}}$ & $251.70 \pm 5.63^{\mathrm{a}}$ & $251.70 \pm 5.63^{\mathrm{a}}$ & $251.70 \pm 5.63^{\mathrm{a}}$ \\
\hline $\mathrm{SOD}(\mathrm{U} / \mathrm{ml})$ & $219.20 \pm 14.32$ & $515.80 \pm 6.77^{\mathrm{a}}$ & $303.20 \pm 3.08^{\mathrm{a}}$ & $303.20 \pm 3.08^{\mathrm{a}}$ & $303.20 \pm 3.08^{\mathrm{a}}$ \\
\hline
\end{tabular}

Values are means \pm SD for six rats in each group. Significant at $\mathrm{P}<0.05$. ${ }^{\text {a }}$ Comparison of the control with other groups. ${ }^{\mathrm{b}}$ Comparison of the indoxacarb-treated group with the indoxacarb+VC+Zn -treated groups. 
Table 2: Serum AST and ALT enzyme activity and HDL-C, LDL-C, total protein, and albumin levels in control and experimental rats.

\begin{tabular}{|l|l|l|l|l|l|}
\hline \multicolumn{1}{|c|}{ Groups } & \multicolumn{1}{|c|}{$\begin{array}{c}\text { Control } \\
\text { group }\end{array}$} & $\begin{array}{c}\text { Indoxacarb- } \\
\text { treated group }\end{array}$ & $\begin{array}{c}\text { Indoxacarb } \\
\text { +VC treated } \\
\text { group }\end{array}$ & $\begin{array}{c}\text { Indoxacarb+Zn } \\
\text { treared group }\end{array}$ & $\begin{array}{c}\text { Indoxacarb +VC+Zn } \\
\text { treated group }\end{array}$ \\
\hline AST (UL) & $39.27 \pm 0.64$ & $181.30 \pm 0.82^{\mathrm{a}}$ & $95.50 \pm 0.53^{\mathrm{a}}$ & $120.50 \pm 0.71^{\mathrm{a}}$ & $54.10 \pm 1.52^{\mathrm{a}, \mathrm{b}}$ \\
ALT (UL) & $32.10 \pm 1.10$ & $101.90 \pm 2.1^{\mathrm{a}}$ & $85.30 \pm 4.21^{\mathrm{a}}$ & $92.30 \pm 0.83^{\mathrm{a}}$ & $44.20 \pm 0.78^{\mathrm{b}}$ \\
HDL-C (mg/dl) & $39.18 \pm 0.77$ & $23.90 \pm 0.74^{\mathrm{a}}$ & $28.60 \pm 0.68^{\mathrm{a}}$ & $21.65 \pm 0.45^{\mathrm{a}}$ & $40.88 \pm 1.62^{\mathrm{b}}$ \\
LDL-C (mg/dl) & $28.48 \pm 0.82$ & $44.70 \pm 0.95^{\mathrm{a}}$ & $39.60 \pm 0.52^{\mathrm{a}}$ & $45.70 \pm 0.43^{\mathrm{a}}$ & $34.70 \pm 0.67^{\mathrm{a}, \mathrm{b}}$ \\
Total protein(g/dl) & $8.30 \pm 0.132$ & $7.23 \pm 0.08^{\mathrm{a}}$ & $7.71 \pm 0.09^{\mathrm{a}}$ & $7.27 \pm 0.08^{\mathrm{a}}$ & $8.98 \pm 0.12^{\mathrm{b}}$ \\
Albumin (g/dl) & $6.12 \pm 0.12$ & $3.11 \pm 0.08^{\mathrm{a}}$ & $3.43 \pm 1.08^{\mathrm{a}}$ & $3.51 \pm 0.09^{\mathrm{a}}$ & $4.36 \pm 0.23^{\mathrm{b}}$ \\
\hline
\end{tabular}

Values are means \pm SD for six rats in each group. Significant at $\mathrm{P}<0.05$. ${ }^{\text {a }}$ Comparison of the control with other groups. ${ }^{\mathrm{b}}$ Comparison of the indoxacarb-treated group with the indoxacarb $+\mathrm{VC}+\mathrm{Zn}$-treated groups.

Table 3: Serum creatinine, urea, uric acid levels, and plasma aldosterone hormone activity in control and experimental rats

\begin{tabular}{|l|c|c|c|c|c|}
\hline \multicolumn{1}{|c|}{ Groups } & $\begin{array}{c}\text { Control } \\
\text { group }\end{array}$ & $\begin{array}{c}\text { Indoxacarb- } \\
\text { treated group }\end{array}$ & $\begin{array}{c}\text { Indoxacarb } \\
+ \text { VC treated } \\
\text { group }\end{array}$ & $\begin{array}{c}\text { Indoxacarb+Zn } \\
\text { treared group }\end{array}$ & $\begin{array}{c}\text { Indoxacarb } \\
+ \text { VC+Zn treated } \\
\text { group }\end{array}$ \\
\hline Creatinine & $0.78 \pm 0.83$ & $0.96 \pm 0.057^{\mathrm{a}}$ & $0.80 \pm 0.10$ & $0.96 \pm 0.057^{\mathrm{a}}$ & $0.766 \pm 0.057^{\mathrm{b}}$ \\
\hline Urea & $37.40 \pm 1.82$ & $62.66 \pm 1.15^{\mathrm{a}}$ & $50.33 \pm 0.57^{\mathrm{a}, \mathrm{b}}$ & $42.66 \pm 4.04^{\mathrm{b}}$ & $38.66 \pm 3.21^{\mathrm{b}}$ \\
\hline Uric acid & $2.08 \pm 0.83$ & $6.66 \pm 0.152^{\mathrm{a}}$ & $3.26 \pm 0.30^{\mathrm{a} . \mathrm{b}}$ & $5.30 \pm 0.30^{\mathrm{a}, \mathrm{b}}$ & $2.30 \pm 0.52^{\mathrm{b}}$ \\
\hline $\begin{array}{l}\text { Aldosterone } \\
\text { hormone }\end{array}$ & $187.64 \pm 32.5$ & $623.4 \pm 122.2^{\mathrm{a}}$ & $476.4 \pm 62.6^{\mathrm{a}}$ & $512.4 \pm 8.8^{\mathrm{a}}$ & $304.6 \pm 37.2^{\mathrm{b}}$ \\
\hline
\end{tabular}

Values are means \pm SD for six rats in each group. Significant at $\mathrm{P}<0.05 .{ }^{\text {a }}$ Comparison of the control with other groups. ${ }^{\mathrm{b}}$ Comparison of the indoxacarb-treated group with the indoxacarb+VC+Zn -treated groups.

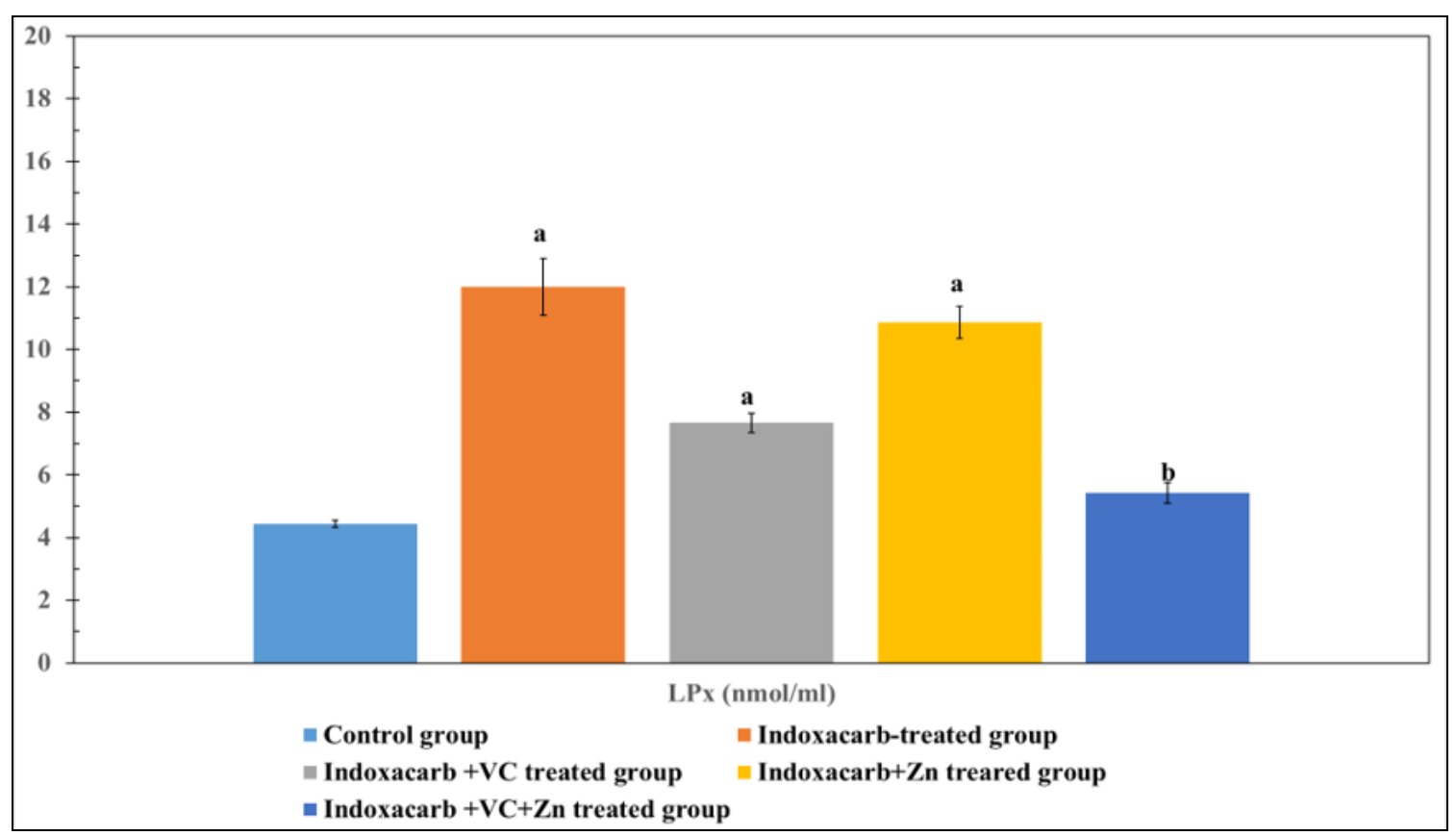

Fig. 2: Plasma LPx level in control and experimental rats. Values are means \pm SD for six rats in each group. Significant at $\mathrm{P}<0.05$. ${ }^{\text {a }}$ Comparison of the control with other groups. ${ }^{\mathrm{b}}$ Comparison of the Indoxacarb-treated group with the Indoxacarb $+\mathrm{VC}+\mathrm{Zn}$-treated groups. 


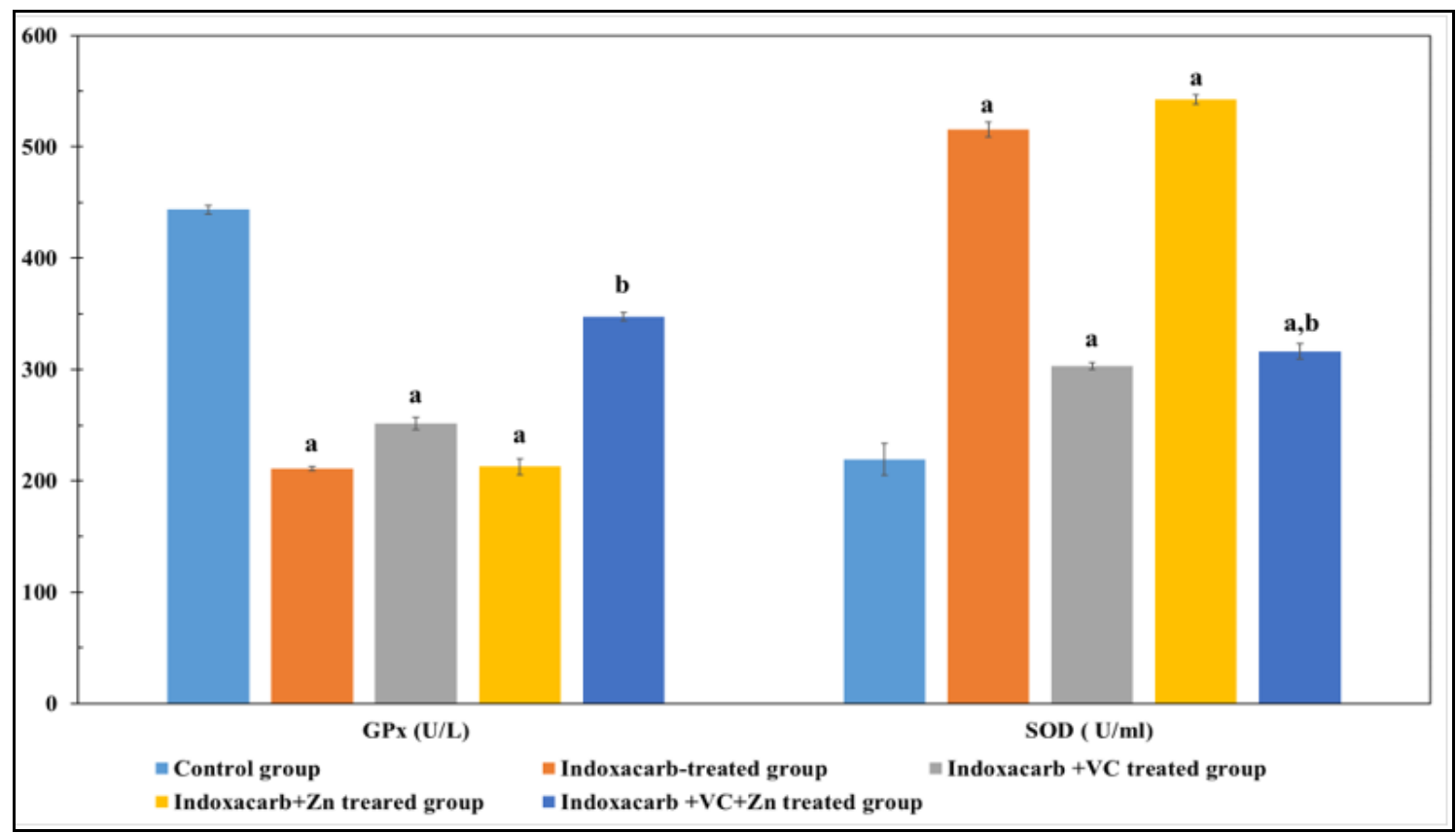

Fig 3: P.lasma GPx and SOD enzyme activity in control and experimental. Values are means \pm SD for six rats in each group. Significant at $\mathrm{P}<0.05$. ${ }^{\mathrm{a}}$ Comparison of the control with other groups. ${ }^{\mathrm{b}}$ Comparison of the Indoxacarb-treated group with the Indoxacarb $+\mathrm{VC}+\mathrm{Zn}$-treated groups.

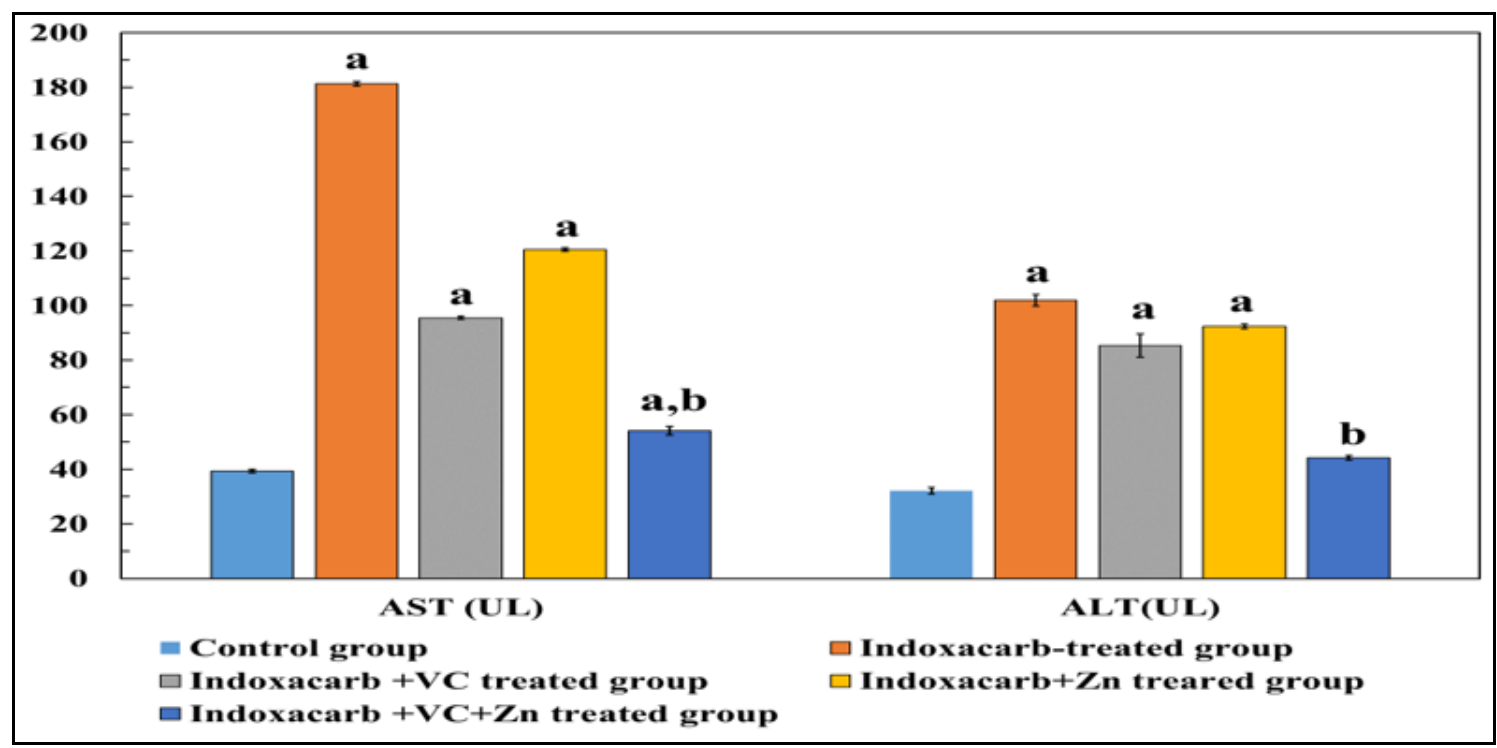

Fig. 4: Serum AST and ALT enzyme activity in control and experimental rats. Values are means \pm SD for six rats in each group. Significant at $\mathrm{P}<0.05$. ${ }^{\text {a }}$ Comparison of the control with other groups. ${ }^{\mathrm{b}}$ Comparison of the Indoxacarb-treated group with the Indoxacarb $+\mathrm{VC}+\mathrm{Zn}$-treated groups. 


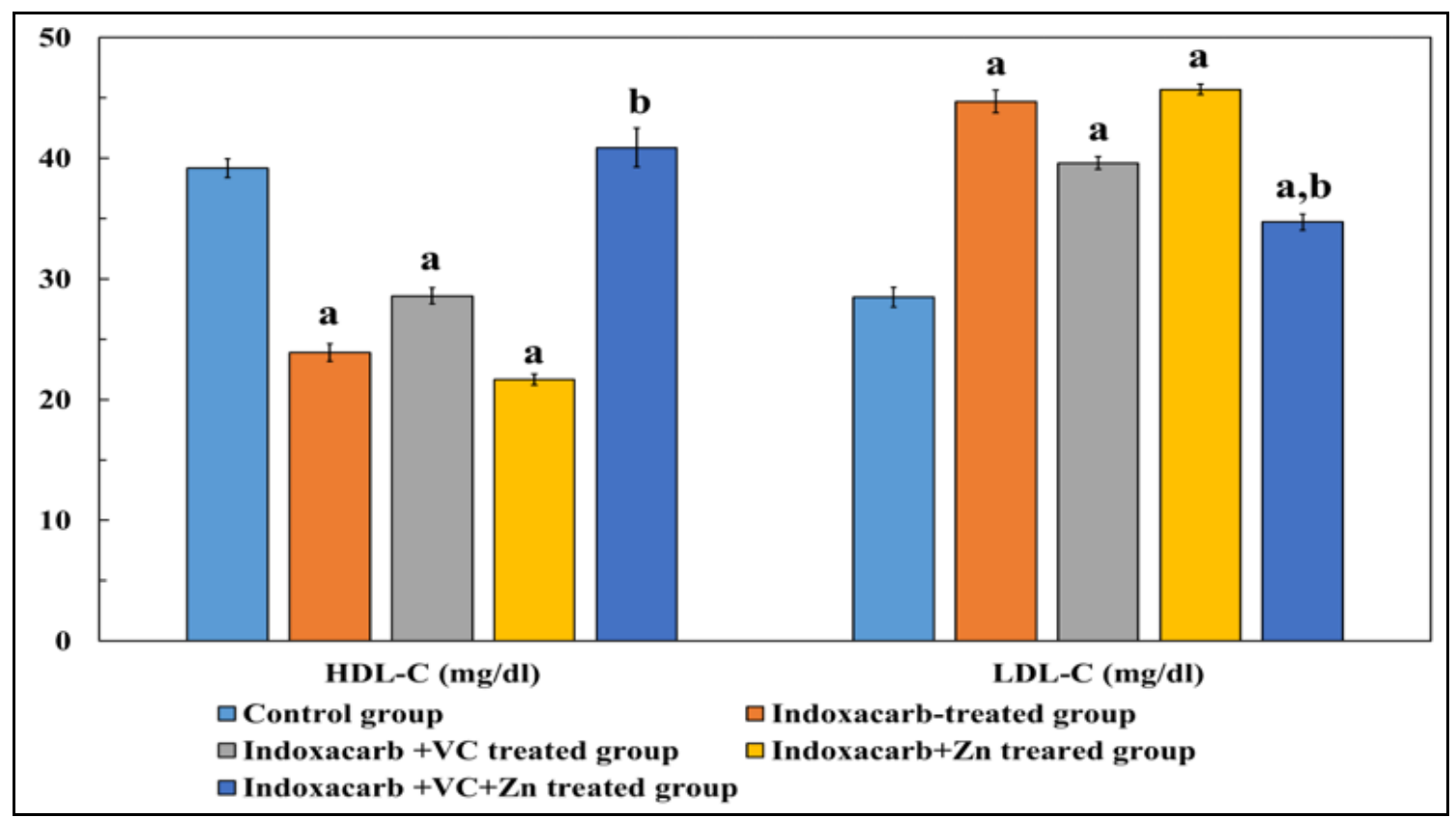

Fig. 5: Serum HDL-C and LDL-C levels in control and experimental rats. Values are means \pm SD for six rats in each group. Significant at $\mathrm{P}<0.05$. ${ }^{\text {a }}$ Comparison of the control with other groups. ${ }^{b}$ Comparison of the Indoxacarb-treated group with the Indoxacarb $+\mathrm{VC}+\mathrm{Zn}$-treated groups.

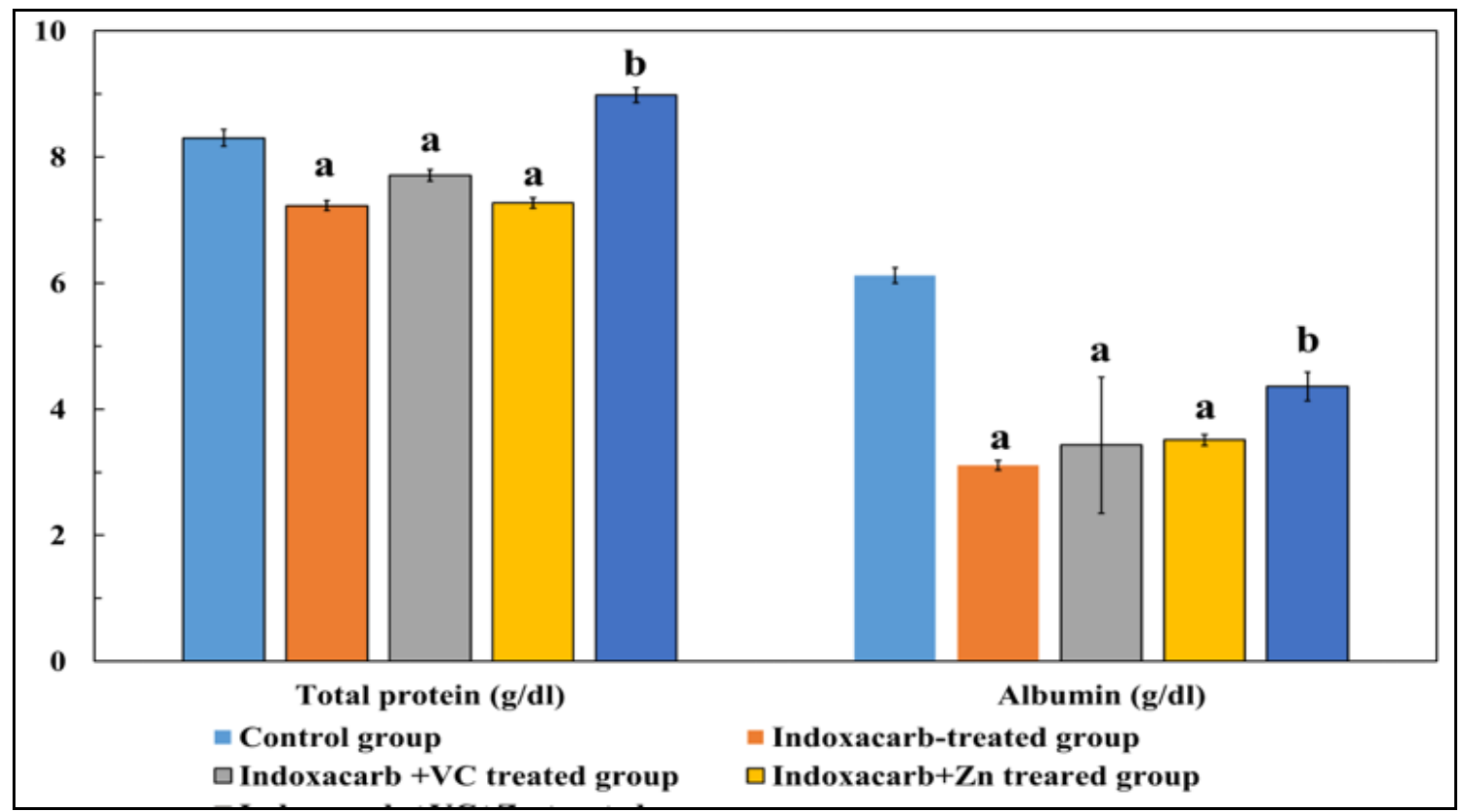

Fig. 6: Serum total protein and albumin levels in control and experimental rats. Values are means \pm SD for six rats in each group. Significant at $\mathrm{P}<0.05$. ${ }^{\text {a }}$ Comparison of the control with other groups. ${ }^{b}$ Comparison of the Indoxacarb-treated group with the Indoxacarb $+\mathrm{VC}+\mathrm{Zn}$-treated groups. 


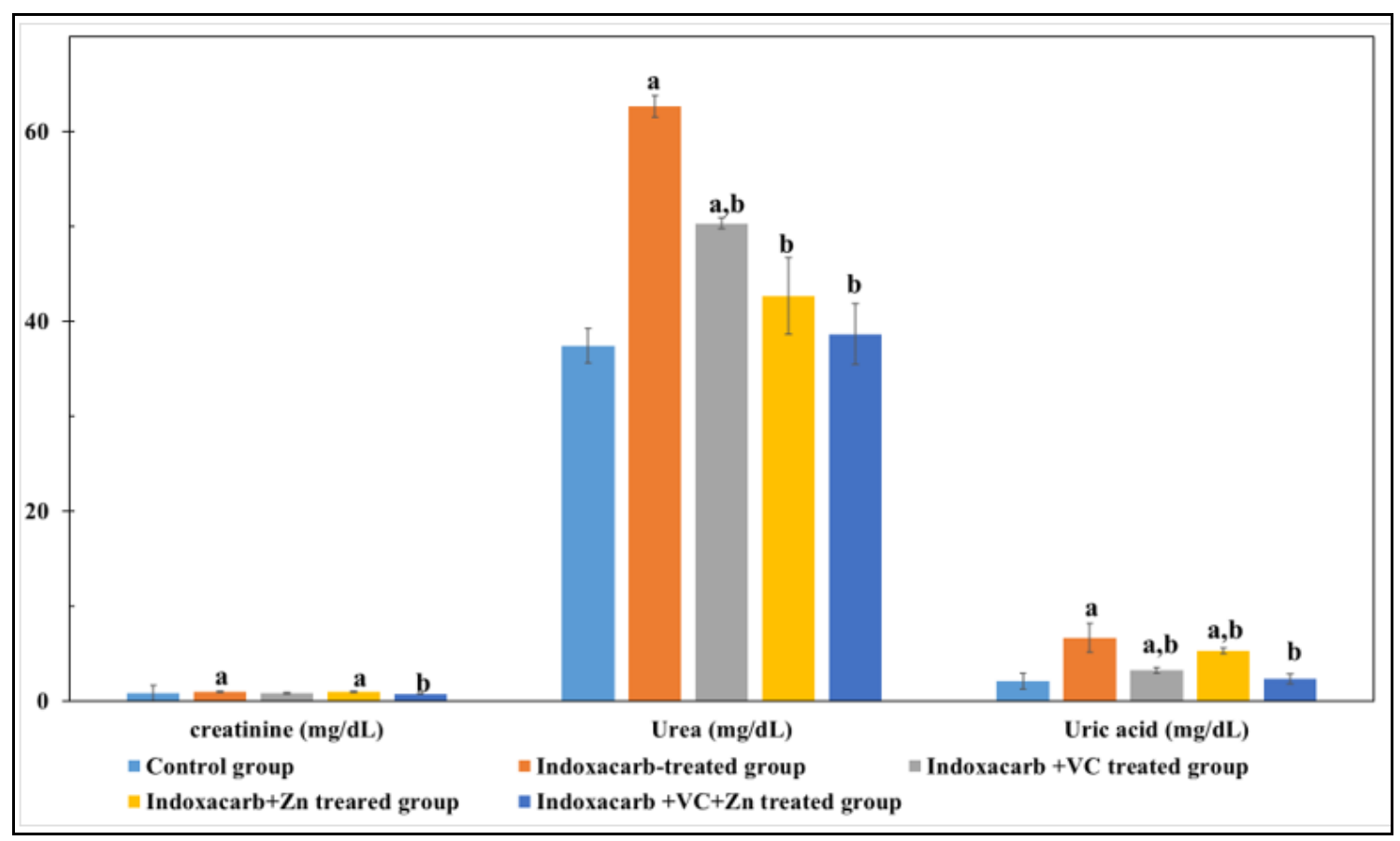

Fig. 7: Serum creatinine, urea, and uric acid levels in control and experimental rats. Values are means \pm SD for six rats in each group. Significant at $\mathrm{P}<0.05$. ${ }^{\text {a }}$ Comparison of the control with other groups. ${ }^{\mathrm{b}}$ Comparison of the Indoxacarb-treated group with the Indoxacarb $+\mathrm{VC}+\mathrm{Zn}$-treated groups.

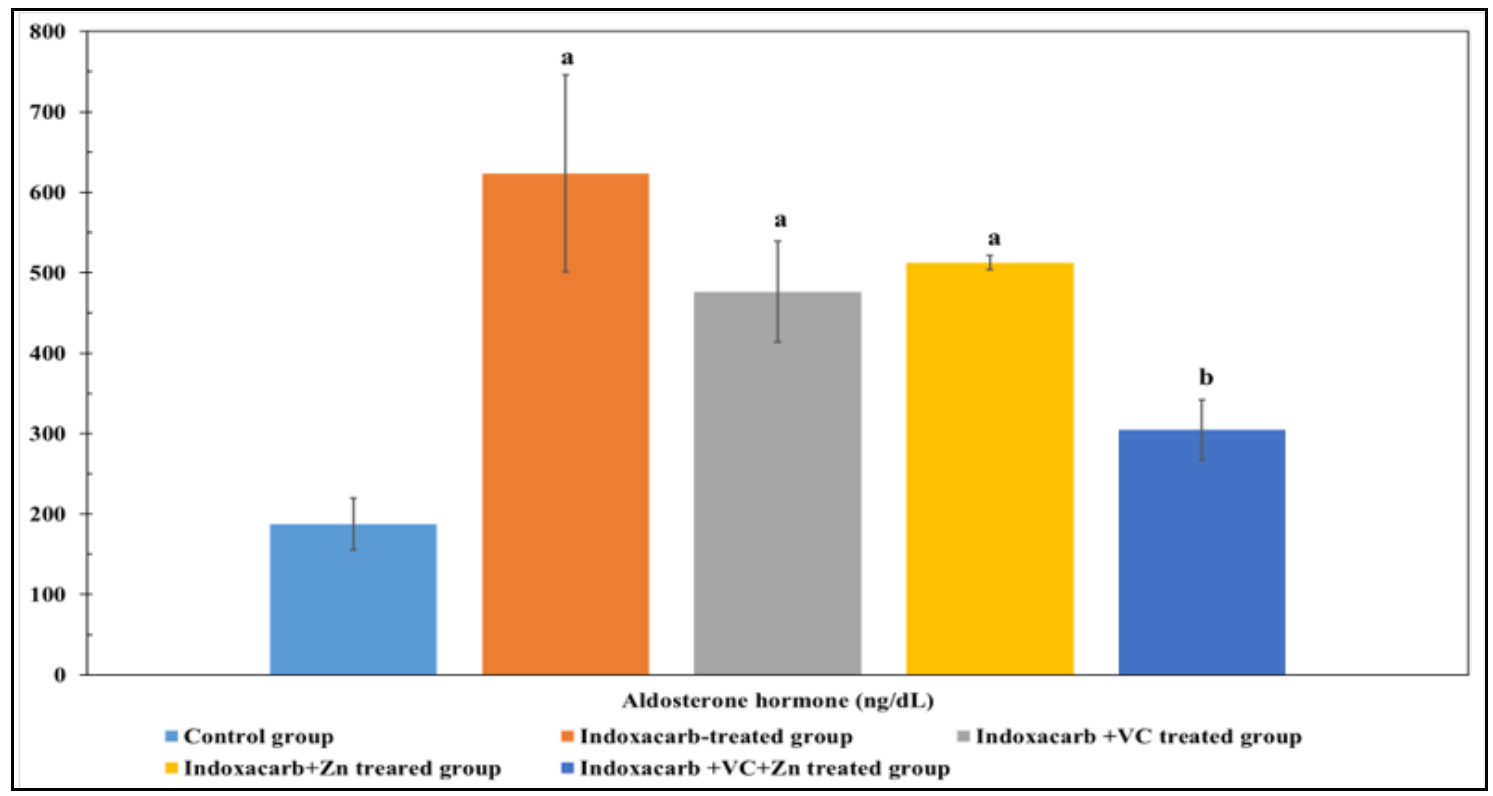

Fig. 8: Serum aldosterone activity in control and experimental rats. Values are means \pm

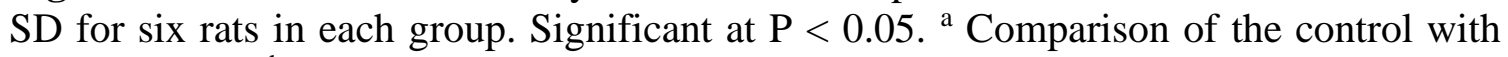
other groups. ${ }^{b}$ Comparison of the Indoxacarb-treated group with the Indoxacarb $+\mathrm{VC}+\mathrm{Zn}$-treated groups.

Histological examination of liver and kidney

\section{1-Histological changes of the liver:}

Microscopic examination of liver H\&E-stained sections of the liver of the (control) group showed normally arranged hepatocytes in cords (Fig. 9A). Sections of the Indoxacarb treated group of rats revealed severe damage in the form of severe necrosis, cell ballooning and 
fatty changes. Inflammatory cell infiltration was marked in addition to the hemorrhagic infiltration of sinusoids (Fig. 9B). The hepatic tissue examined of both groups (Indoxacarb+Zn) (Fig. 9C) and (Indoxacarb+VC) (Fig. 9D) showed nearly similar results with marked protection against the toxic effect of the Indoxacarb.

Hepatocellular damage was minimal among rats treated with combined Indoxacarb+ Zn+VC (Fig. 9E). Microscopic examination of the liver of animals treated with (Indoxacarb+ VC+ $\mathrm{Zn})$ showed mild toxic effects indicating an effective protective role.
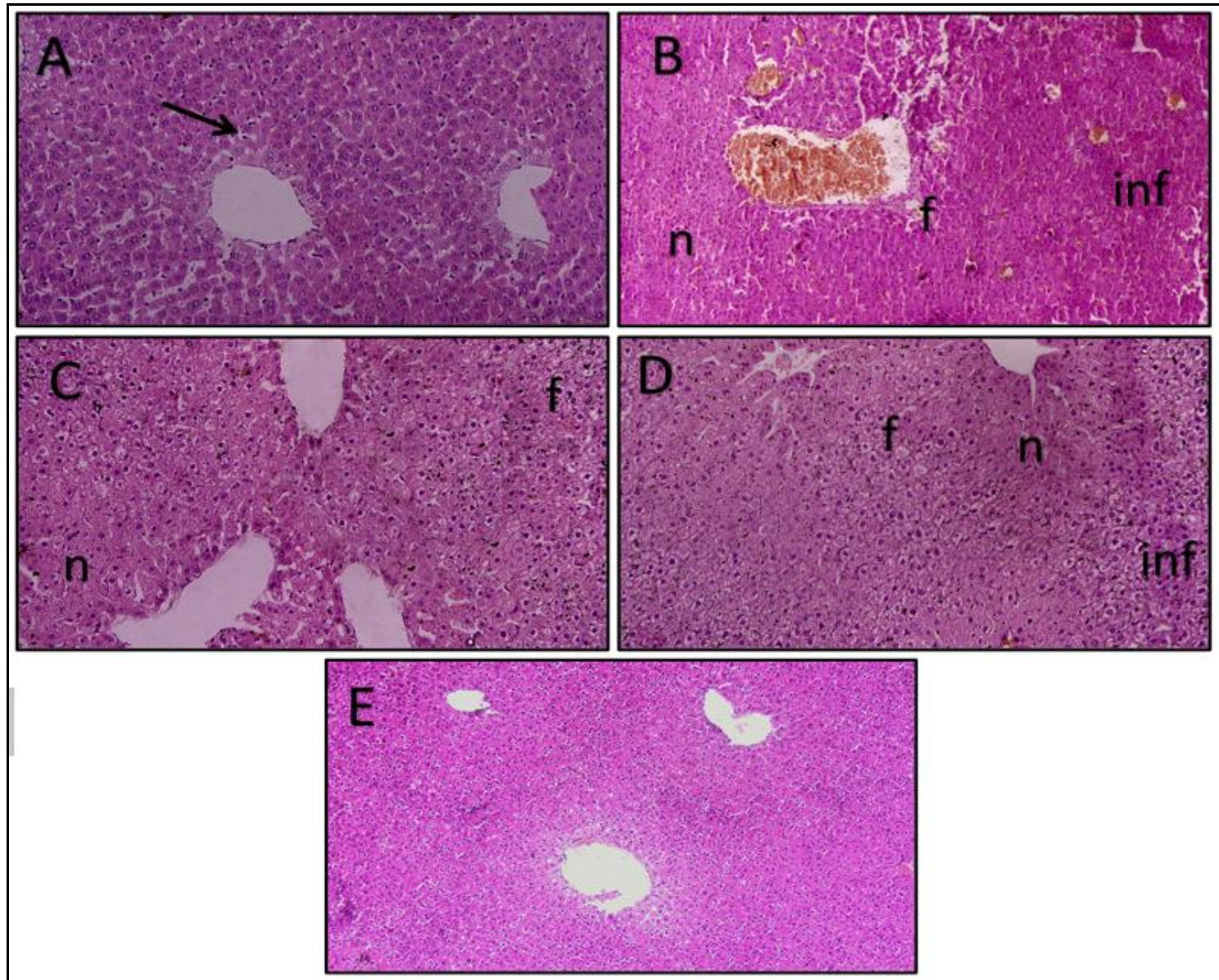

Fig. 9: Photomicrograph of different liver sections stained with H\&E. (A) liver section from control rats showing normal hepatic architecture with normal hepatocytes (arrow). (B) Liver sections of the Indoxacarb treated rats show multiple large-sized areas of necrotic hepatocytes (n) with vacuolated cytoplasm and fatty change (f) and wide areas of inflammation (inf) with the loss of hepatic lobular architecture. Liver section from rats of both groups that received (C) (Indoxacarb+Zn) and (D) (Indoxacarb+VC) showed mild improvement of liver degeneration with moderate degeneration. (E) (Indoxacarb+ $\mathrm{Zn}+\mathrm{VC}$ ) treatment markedly decreased hepatic damage and inflammatory infiltration which are restricted to few hepatocytes with mild vacuolation of their cytoplasm while the nuclei appear normal with the restoration of normal lobular architecture mimic to control.

\section{2-Histological changes of the kidney:}

Microscopic examination of kidneys sections stained by $H \& E$ of the (control) group showed normal renal architecture of the cortex and medulla and the glomeruli structure in addition to both proximal and distal tubules (Fig. 10A). Sections of the Indoxacarb treated group 
of rats revealed severe damage in the form of severe necrosis of the glomeruli and tubules, cell ballooning and cloudy swelling. Inflammatory cell infiltration was marked in addition to a marked loss of the normal renal architecture (Fig. 10B). The renal tissues examined of both groups (Indoxacarb+Zn) (Fig. 10C) and (Indoxacarb+VC) (Fig. 10D) showed nearly similar results with valuable protection against the toxic effect of the Indoxacarb. Renal damage was minimal among rats treated with combined Indoxacarb+ $\mathrm{Zn}+\mathrm{VC}$ (Fig. 10E). Microscopic examination of the kidneys of animals treated with (Indoxacarb+ $\mathrm{VC}+$ $\mathrm{Zn})$ showed mild toxic effects indicating an effective protective role.

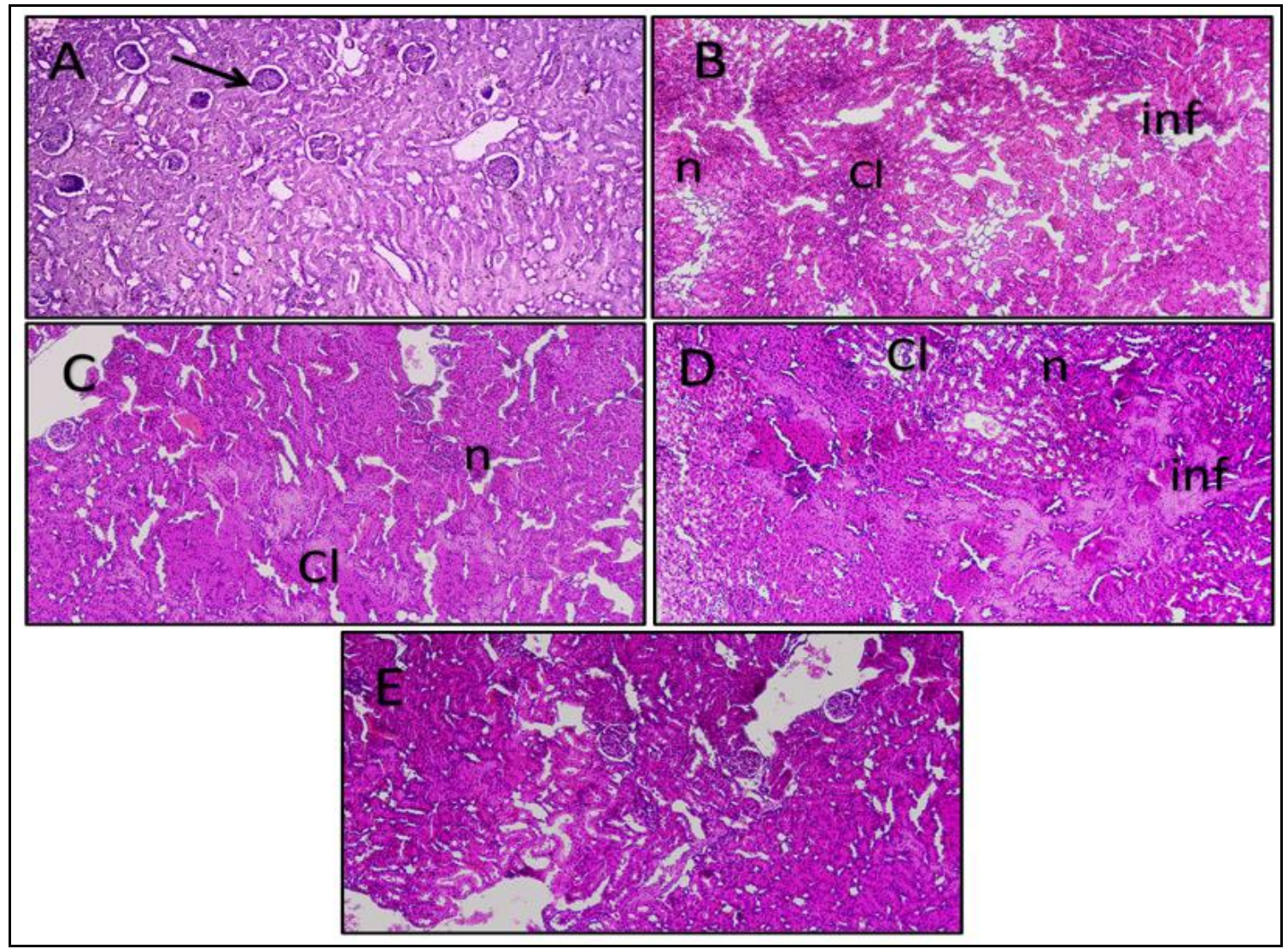

Fig. 10: Photomicrograph of different kidney sections stained with H\&E. (A) kidney section from control rats showing normal renal architecture with normal glomeruli (arrow). (B) Kidney sections of the Indoxacarb treated rats show multiple large-sized areas of necrotic cells $(\mathrm{n})$ with vacuolated cytoplasm and cloudy swelling $(\mathrm{Cl})$ and wide areas of inflammation (inf) with the loss of normal renal architecture. Sections from kidney of rats of both groups that received (C) (Indoxacarb+Zn) and (D) (Indoxacarb+VC) showed mild protection of renal tissue with moderate degeneration. (E) (Indoxacarb+ $\mathrm{Zn}+\mathrm{VC}$ ) treatment markedly decreased renal damage and inflammatory infiltration which are restricted to few foci with mild vacuolation of their cytoplasm while the nuclei appear normal with the restoration of normal architecture mimic to control.

Immunohistochemical assessment of with the anti-iNOS primary antibody show iNOS:

1-Immunohistochemical staining of the liver by iNOS:

Liver sections that Immunostained different expression intensities among different groups of studied rats (Fig. 11). Liver sections from the normal control group show negative immune reactivity 
(Fig. 11A). Liver sections from rats received Indoxacarb show a marked increase of the strongly positive immunostained hepatocytes between a few unstained hepatocytes (Fig. 11B). Liver sections from rats received (Indoxacarb+ Zn) (Fig. 11C) show moderate immunopositive hepatocytes between many unstained normal cells. Also, Liver sections from rats received (Indoxacarb+ VC) (Fig. 11D) show moderate immunopositive hepatocytes between many unstained normal cells, Liver sections from rats received combined (Indoxacarb+ $\mathrm{Zn}+\mathrm{VC}$ ) show mild expression as the majority of hepatocytes show negative reactions while positive cells are fewer with weak positivity (Fig. 11E).

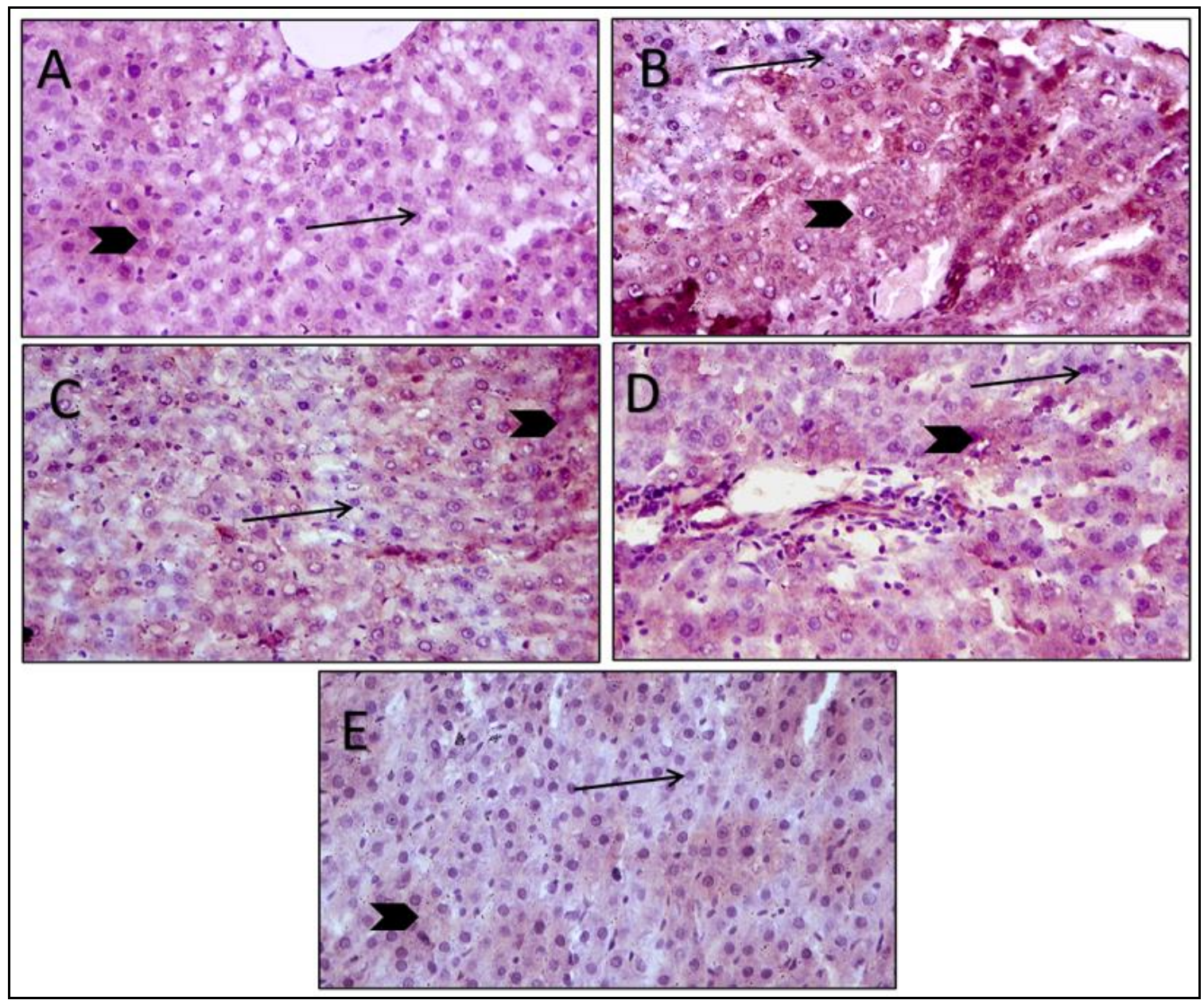

Fig. 11: Photomicrograph of liver sections Immuno-stained with the anti iNOS primary antibody. Immunohistochemistry assessment of iNOS in liver sections showed (A) Liver sections from normal control group shows negative immune reactivity (arrow). (B) shows a marked increase of the strongly positive immunostained hepatocytes (arrowheads) between few unstained hepatocytes (arrow). (C) Liver section from rat received (Indoxacarb $+\mathrm{Zn}$ ) shows moderate immuno-positive hepatocytes (arrowhead) between many unstained normal cells (arrow), (D) Liver section from rat received (Indoxacarb+ VC) shows moderate immuno-positive hepatocytes (arrowhead) between many unstained normal cells (arrow), (E) Liver section from rat received (Indoxacarb+ $\mathrm{Zn}+\mathrm{VC}$ ) shows mild immune-expression as many hepatocytes with immuno-negative reaction (arrow) while immune positive cells are less with weak positivity (arrowhead). 
2- Immunohistochemical Staining of the kidney by iNOS:

Kidneys sections that Immunostained with the anti-iNOS primary antibody show variable expression intensities among studied rats of different groups (Fig. 12). Kidney sections from the normal control group show negative immune reactivity (Fig. 12A). kidney section from rats received Indoxacarb shows a marked increase of the strongly positive immunostained cells between a few other unstained cells (Fig. 12B).
Kidney sections from rats received (Indoxacarb+ Zn) (Fig. 12C) show moderate immuno-positive cells between many unstained normal cells. Similarly, sections from rats received (Indoxacarb+ VC) (Fig. 12D) show moderate immunopositive cells between many unstained normal cells. Kidneys sections from rats received combined (Indoxacarb $+\mathrm{Zn}+\mathrm{VC}$ ) show mild expression as most of the cells with a negative reaction while positive cells are fewer with weak positivity (Fig. 12E).

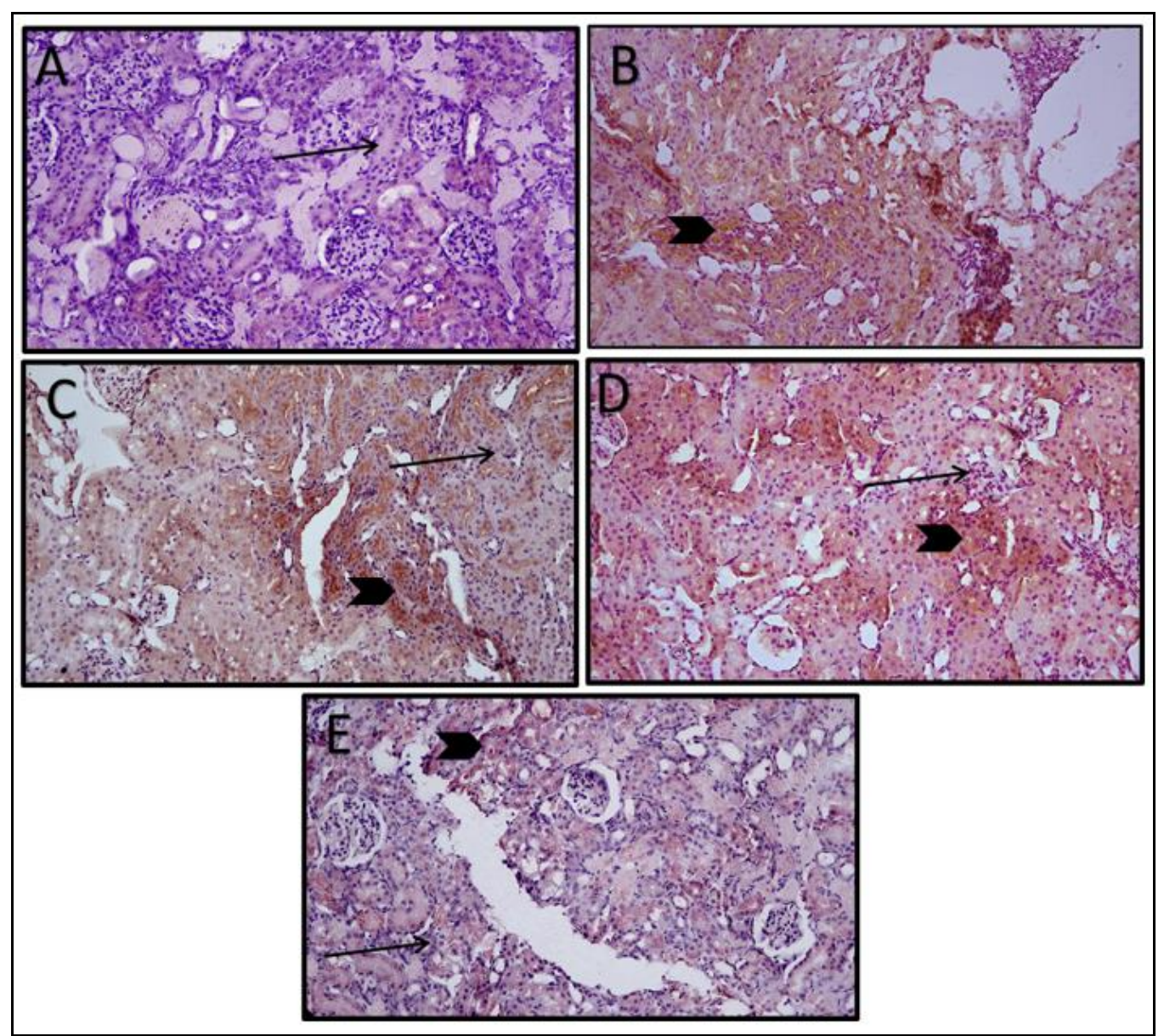

Fig. 12: Photomicrograph of kidney sections Immunostained with the anti iNOS primary antibody. Immunohistochemical assessment of iNOS in kidney sections showed (A) kidney sections from normal control group shows negative immune reactivity (arrow). (B) shows a marked increase of the strongly positive immunostained renal cells (arrowheads) between few unstained cells (arrow). (C) kidney section from rat received (Indoxacarb+ Zn) shows moderate immuno-positive cells (arrowhead) between many unstained normal cells (arrow), (D) kidney section from rat received (Indoxacarb+ VC) shows moderate immuno-positive cells (arrowhead) between many unstained normal cells (arrow), (E) kidney section from rat received (Indoxacarb+ $\mathrm{Zn}+\mathrm{VC}$ ) shows mild immune-expression as many cells with immuno-negative reaction (arrow) while immune positive cells are less with weak positivity (arrowhead). 


\section{DISCUSSION}

Indoxacarb is considered an organophosphate replacement, it was initially classified as a "moderately to very highly toxic" compound for aquatic organisms (Ghelichpour et al., 2019). As previously reported, Swiss albino mice were given different doses of indoxacarb with the sub-acute level of toxicity for 30 days that induced ROS production and caused oxidative stress (Mudaraddi et al., 2012). Our current research showed the sublethal dose of indoxacarb $(100 \mathrm{mg} / \mathrm{kg})$ induced a significant rise in LPx level (Fig. 2) and significant changes in antioxidant enzymes (GPx and SOD) activity (Fig. 3). Mudaraddi et al. (2012) indicated that indoxacarb induces oxidative stress as evidenced by the high level of LPx which is an indication of the generation of free radicals as the antioxidant mechanism failed to regulate them. It is well-known that antioxidant enzymes are the first-line defense against ROS (Marti'nez-A'lvarez et al., 2005). The increased SOD activity detected in this study could indicate the need to encounter the increase in ROS production by the indoxacarb as SOD comprises an important ROS-scavenging enzyme. An antioxidant enzyme (SOD) catalyzes the alteration of superoxide anions to hydrogen peroxide $\left(\mathrm{H}_{2} \mathrm{O}_{2}\right)$. Therefore, the decreased GPx activity observed in this study led to the continuous generation and accumulation of ROS such as $\mathrm{H}_{2} \mathrm{O}_{2}$ under the influence of exposure to indoxacarb toxicity thus increasing oxidative stress and disturbance in the antioxidant mechanism (Monteiro et al., 2019).

In general, according to the present study, the improvement induced by the mixture of $\mathrm{VC}$ and $\mathrm{Zn}$ (the examined doses) against indoxacarb toxicity was greater than that recorded for each of them individually and $\mathrm{VC}$ seems to be more effective than $\mathrm{Zn}$ to a small extent. A combination of $\mathrm{VC}$ and $\mathrm{Zn}$ can reduce lipid peroxidation caused by indoxacarb and act as antioxidant scavenging free radicals. There are several publications that reported the ameliorative role of the antioxidants that used in the present study against different types of toxicants. Hamden et al. (2009) reported that VC is a very important and powerful antioxidant; It could minimize cell damage caused by free radicals by increasing activities of SOD and GPx and improving the antioxidant defense mechanism. In the same line, Mossa et al. (2011) suggested that the ameliorating effects of VC might be due to the inhibition of the generation of free radicals along with the free radical scavenging activity. Moreover, Banerjee $e t$ al. (2009) showed that VC opposed arsenic (As) induced oxidative stress in mice livers. Furthermore, El-Demerdash $e t$ al. (2005) showed the ameliorative role of VC against toxicity induced by stannous chloride in the liver of treated rats, as it decreased levels of free radicals and improved liver architecture. VC also has been shown to overwhelm the oxidative stress caused by acute exposure to chlopyrifos in Wistar rats (Ambali and Ayo, 2011). Powell (2000) reported that zinc, the second most abundant trace element in the body, tends to protect against oxidative stress by several ways, such as preventing or minimizing ROS formation and minimizing the primary effect of such stress on the cell. Additionally, earlier studies have shown the ameliorative effects of $\mathrm{Zn}$ against oxidative stress induced by chlorpyrifos toxicity (Ambali et al., 2011). Besides, the experiments done by Hfaiedh et al. (2012) confirmed that administration of $\mathrm{Zn}+\mathrm{Mg}$ to Wister rats decreases hepatotoxicity and neurotoxicity caused by lindane toxicity. From our current study, VC and Zn acted together to overcome the oxidation stress and protect the rats from indoxacarbevoked lipid peroxidation and free radicals' generation.

The liver is an essential organ in purifying the body from toxins. 
Consequently, any disruption or impairment of its function led to hepatotoxicity and hazardous effects on health. AST and ALT (Fig. 4) are liver enzymes that detect hepatic dysfunction (Khaldoun-Oularbi et al., 2013). In this work, a significant increase was observed in serum AST and ALT enzymes activity in indoxacarb-treated rats compared to the normal rats. Previous reports demonstrated that the disturbance in hepatic enzymes activities confirms the destruction of the hepatocyte membrane and allows these enzymes to leak into the circulation (Abdelrasoul, 2018). The high liver enzymes activity revealed in this study is consistent with the hepatic toxicity induced by indoxacarb toxicity.

Our present study indicated a significant decrease in serum level of HDL-C and a significant increase in serum LDL-C level in rats treated with indoxacarb compared to the control rats (Fig. 5). Moreover, comparable results were obtained from the previous study conducted on rats exposed to many pesticides as Coragen (Meligi et al., 2019) and Chlorpyrifos (Ambali et al., 2011). Hepatocytes and intestines are the principal sites for HDL-C synthesis. The decreased HDL-C level can be a sign of liver damage leading to obstruction of bile ducts causing a decrease or a closure of the liver duodenum secretion. HDL-C plays a significant function in the efflux of cholesterol from the cells and returns it to the liver for bile acid removal (Shakoori et al., 1988). On the other side, the elevated level of LDL-C may be due to indoxacarb treatment that suppresses the formation of new LDL receptors and thus reduce the LDL-C intake by the cells. Also, the increase in LDL-C level as previously reported in Chlorpyrifos - treated rats related to the decrease in VLDL-C level due to stimulation of the harmful alteration of some VLDL-C to LDL-C (Ambali et al., 2011).

Our results reflected the obvious substantial decrease in serum level of total proteins besides albumin in the indoxacarb-treated group in comparison with the control group (Fig. 6). Veeraiah et al. (2013) reported a decrease in protein content in different tissues (liver, kidney, muscles, gills, and brain) in freshwater fishes exposed to different pesticides as indoxacarb. The liver is also a major organ for the synthesis of different proteins besides being the center of metabolism regulation. Exposure to pesticides can cause damage to hepatocytes leading to disorders of liver function with reduced protein synthesis and increased wasting by catabolism (El-Shafey et al., 2011).

The kidney excretes creatinine, urea, and uric acid is the end products of protein catabolism (Refaie et al., 2014). Our results indicated a significant increase in serum creatinine, urea and uric acid levels in rats treated with indoxacarb compared to the control rats (Fig. 7). These latter results are correlated with increased protein catabolism and may be confirmed a disturbance in glomerular filtration and functional damage in the kidney (Walmsley and White, 1994 and Abdelrasoul, 2018).

The adrenal glands secrete an aldosterone hormone that regulates the reabsorption of sodium and excretion of potassium of the kidney, fluids preservation or loss and blood pressure control (Ponda and Hostetter 2006). These current results demonstrated a significant rise in the activity of plasma aldosterone hormone after indoxacarb administration compared to the control group (Fig. 8). A significant increase in aldosterone hormone activity may be due to the surplus secretion frequently from a small benign adrenal tumor (hyperaldosteronism). It leads to high blood pressure (arterial hypertension) associated with low blood levels of potassium (hypokalemia) (Schaefer and Wolford 2005). Disturbance of aldosterone hormone activity is pathogenic and associated with the progression and development of cardiovascular 
diseases and kidney dysfunction (Gajjala et al., 2015). The clinical application indicated certain hypokalemia complications that may cause muscle weakness and cramps. This is supported by our results in which indoxacarb was noted to induce muscle cramps in indoxacarb-treated rats.

Our results showed that a mixture of $\mathrm{VC}$ and $\mathrm{Zn}$ improved the liver and kidney damage induced by indoxacarb. The improvement involves a significant decrease in AST, ALT activities (Fig. 4), LDL-C level and a significant increase in HDL-C (Fig. 5), total protein, and albumin levels (Fig. 6) in the blood as compared to indoxacarb-treated rats. In addition, there was a significant decrease in serum creatinine, urea, uric acid levels (Fig. 7), and plasma aldosterone hormone activity (Fig. 8); it should also be noted that a mixture of $\mathrm{VC}$ and $\mathrm{Zn}$ administration offered substantial defense against renal dysfunction.

These results may be attributable to reinstate antioxidant defense mechanisms that suppress free radicals' development. In this regard, as our findings show, supplementation of $\mathrm{VC}$ along with $\mathrm{Zn}$ to indoxacarb-treated rats is preventing the rise in the levels of hepatic transaminases enzymes (Fig. 4) suggestive of the main sign of their hepatoprotective action. Bashandy and Alwasel (2011) reported that $\mathrm{VC}$ was able to preserve the integrity of the cell and normalized levels of AST and ALT in the blood of carbon tetrachloride intoxication rats. In the same line, Attar (2011) showed that the hepatoprotective effect of $\mathrm{VC}$ on thioacetamide-induced liver cirrhosis in rats. Bray and Bettger (1990) indicated that the ameliorative properties of $\mathrm{Zn}$ ions may involve cell membranes stabilization and the increased antioxidant enzymes expression, indicative of the regeneration of hepatocytes and healing of hepatic parenchyma (Thabrew et al., 1987).

Our analysis also showed the apparent substantial decrease in serum
LDL-C and the rise in HDL-C levels (Fig. 5 ) in the group treated with both $\mathrm{VC}$ and $\mathrm{Zn}$ when compared to the indoxacarbtreated group. Paolisso et al. (1995) reported that supplementation of $\mathrm{VC}$ is vital to hepatic metabolism and control of plasma lipids. Farvid et al. (2004) concluded that nutritive supplementation with $\mathrm{Zn}$, vitamins $\mathrm{C}$ and $\mathrm{E}$ exhibited efficacy in lowering the levels of blood cholesterol and triglyceride and may improve HDL-C in diabetic patients by 24 percent. In the same line, AfkhamiArdekani and Shojaoddiny-Ardekani (2007) stated that a daily intake of $1 \mathrm{gm}$ of $\mathrm{VC}$ in diabetic patients (type 2) can be beneficial in decreasing blood lipid levels. The particles of LDL are dense and small in diabetes (type 2) and so vulnerable to oxidation, while VC is needed for restoration of $\alpha$-tocopherol and may therefore prevent LDL oxidation (Mullan et al., (2002).

In this study, we observed a substantial increase in both serum total proteins and albumin (Fig. 6) in $\mathrm{VC}+\mathrm{Zn}$ treated group compared to the indoxacarbtreated group. Bader et al. (2016), showed that treatment with VC (100 or $200 \mathrm{mg} / \mathrm{kg}$ diet) plus lead significantly increased serum total proteins and albumin, suggesting that VC can reduce liver toxicity induced by lead. Sandstead et al. (2000) suggested that $\mathrm{Zn}$ is important for coenzyme synthesis which catalyzes the synthesis and metabolism of biogenic amine. In view of the abovementioned points, it is considered that $\mathrm{VC}$ and $\mathrm{Zn}$ could increase the protein synthesis in the injured liver and improve the function of its hepatocytes.

From our study, a mixture of VC and $\mathrm{Zn}$ significantly decrease serum creatinine, urea, uric acid levels (Fig. 7) and plasma aldosterone hormone activity (Fig. 8). El Mashad et al. (2016) stated that administration of VC significantly reduced serum creatinine, urea, and uric acid level in STZ- diabetic rats in comparison with the control group. The 
mechanisms by which VC decreased serum creatinine and urea levels may inhibit the development of diabetic nephropathy by suppressing apoptosis and protecting all groups of lipids from oxidation under several related oxidant stress forms. Treatment with VC decreased serum uric acid may be attributed to increased glomerular filtration and/or renal reabsorption competition, i.e., both VC and uric acid are reabsorbed at the proximal tubules by anion exchange transport (Sutton et al., 1983). Possible explanations for increased glomerular filtration include an antioxidant effect in glomeruli that decreases microvascular ischemia and results in increased blood flow at the site, dilation of afferent arterioles, and competition for reabsorption with ions such as sodium and potassium that exerts osmotic effects. Vitamin $\mathrm{C}$ helps in the regulation or removal of renal injury progression in diabetic rats (El Mashad et al., 2016). Zinc is a micronutrient that plays a significant role in human physiology from its involvement in the proper functioning of the immune system to its role in cell development, cell proliferation, cell apoptosis, and in the action of various zinc-binding proteins. In turn, zinc is an anti-inflammatory antioxidant, and controls innate and adaptive immune reactions, making it essential to infection resistance (Escobedo-Monge et al., 2019). Mousavi et al. (2018) displayed a significant improvement in kidney functions after supplementation of $\mathrm{Zn}$ (50 $\mathrm{mg}$ /day) in adult's patients with renal insufficiency relative to healthy subjects. Escobedo-Monge et al., (2019) showed that $\mathrm{Zn}$ supplementation could be useful for nutritional status in children and adolescents with chronic kidney disease as participants could have improved their nutritional status by substantially raising their body mass.

\section{Compliance With Ethical Standards}

All experimentation, transportation, and care of the animals used in this study were following the Faculty of Science, Minia University's policy on animal use and ethics. All mandatory laboratory health and safety measures have been adhered to while performing the experimental work of this study.

\section{Conflict of Interest}

The authors declare that they have no conflict of interest.

\section{Funding}

The authors declare that no funding was received for this work.

\section{REFERENCES}

Abdelrasoul MA (2018): Modulation of Abamectin and Indoxacarb Induced Toxicity on Male Albino Rats by Moringa oleifera. Alexandria Science Exchange Journal, 39(2): 232- 243.

Afkhami-Ardekani M, ShojaoddinyArdekani A (2007): Effect of vitamin $\mathrm{C}$ on blood glucose, serum lipids \& serum insulin in type 2diabetes patients. The Indian Journal of Medical Research, 126: 471-474.

Ali FF, Abdel-Hamid HA and Toni NDM (2018). $\mathrm{H}_{2} \mathrm{~S}$ attenuates acute lung inflammation induced by administration of lipopolysaccharide in adult male rats. General Physiology and Biophysics, 37: 421-431.

Ambali SF, Abubakar AT, kawu MU, Uchendu C, Shittu M, Salami SO (2011): Biochemical alternations induced by sub chronic chlorpyrifos exposure in Wister rats: Ameliorative effect of zinc. The Journal of American Science, 7(9): 73-81.

Ambali SF, Ayo JO (2011): Sensorimotor performance deficits induced by chronic chlorpyrifos exposure in Wistar rats mitigative effect of vitamin C. Toxicological and Environmental Chemistry, 93: 1212-1226.

Attar, AM (2011): Hepatoprotective influence of vitamin $\mathrm{C}$ on 
Thioacetamide induced liver cirrhosis in Wistar male rats. Journal of Pharmacology and Toxicology, 6(3): 218-233.

Badimon JJ, Badimon L, Fuester V (1990): Regression of atherosclerotic lesions by high-density lipoprotein plasma fraction in the cholesterol-fed rabbit. The Journal of Clinical Investigation, 85:1234-1241.

Badr MI, Abd-Elhamid AA, Qassim SH (2016): Protective effect of vitamin $\mathrm{C}$ on amelioration of hematological and biochemical toxicity induced by lead in male rats. Current science international, 5(1): 44-50.

Banerjee P, Bhattacharyya SS, Bhattachrjee N (2009): Ascorbic acid combats Arsenic- induced oxidative stress in mice liver. Ecotoxicology and Environmental Safety, 72(2): 639-649.

Bashandy SA, Alwasel SH (2011): Carbon Tetrachloride-induced hepatotoxicity and nephrotoxicity in rats: protective role of vitamin C. Journal of Pharmacology and Toxicology, 6(3): 283-292.

Bergmeyer HU, Horder M, Rej R (1986): IFCC method for alanine aminotransferase (L-alanine: 2oxoglutrate aminotransferase, EC 2.6.1.2). Journal of Clinical Chemistry and Clinical

Biochemistry, 24:481-495.

Bettger WJ, O'Dell BL (1993): Physiological roles of zinc in the membrane of mammalian cells. The Journal of Nutritional Biochemistry, 4: 194-207.

Bray TM, Bettger WJ (1990): The physiological role of zinc as an antioxidant. Free Radical Biology and Medicine, 8: 281-91.

Cartledge S, Lawson N (2000): Aldosterone and renin measurements. Annals of Clinical Biochemistry, 37: 262-278.
Doumas BT, Bayse DD, Carter RJ, Peters TJr, Schaffer R (1981): A candidate reference method for determination of total protein in serum. I. Development and validation. Clinical Chemistry, 27: 1642-1650.

Durak D, Uzun FG, Kalender S, Ogutcu A, Uzunhisarcikli M, Kalender Y (2009): $\quad$ Malathion-induced oxidative stress in human erythrocytes and the protective effect of vitamins $\mathrm{C}$ and $\mathrm{E}$ in vitro. Environmental Toxicology, 24 (3): 235-242.

El Mashad GM, ElSayed HM, Nosair NA (2016): Effect of Vitamin C supplementation on lipid profile, Serum Uric Acid, and Ascorbic Acid in Children on Hemodialysis. Saudi Journal of Kidney Diseases and Transplantation, 27(6):11481154.

El-Demerdash FM, Yousef MI, Zoheir MA (2005): Stannous Chloride induces alterations in enzyme activities, lipid peroxidation and histopathology in male rabbits: antioxidant role of vitamin $\mathrm{C}$. Food and Chemical Toxicology, 43(12): 1743-1752.

El-Shafey AM, Seliem ME, El-Mahrouky F, Gabr WM, Kandil RA (2011): Some physiological and biochemical effects of Oshar extract and abamectin biocide on male albino rats. The Journal of American Science, 7 (12): 254261.

Escobedo-Monge MF, Ayala-Macedo G, Sakihara G, Peralta M, AlmarazGómez A, Barrado E, MarugánMiguelsanz JM (2019): Effects of Zinc Supplementation on Nutritional Status in Children with Chronic Kidney Disease: A Randomized Trial. Nutrients, 11: 2671, 1-20.

Farvid MS, Siassi F, Jalali M, Hosseini M, Saadat N (2004): The impact of 
vitamin and/or mineral supplementation on lipid profiles in type 2 diabetes. Diabetes Research and Clinical Practice, 65:21-8.

Gajjala PR, Sanati M, Jankowski J (2015): Cellular and molecular mechanisms of chronic kidney disease with diabetes mellitus and cardiovascular diseases as its comorbidities. Frontiers in Immunology, 6: 340.

Ghelichpour M, Mirghaed AT, Hoseinifar SH, Khalili M, Yousefi M, Doan HV, Perez-Jimenez A (2019): Expression of immune, antioxidant and stress related genes in different organs of common carp exposed to indoxacarb. Aquatic Toxicology, 208: 208-216.

Goel A, Dani V, Dhawan DK (2005): Protective effects of zinc on lipid peroxidation, antioxidant enzymes and hepatic histoarchitecture in chlorpyrifosinduced toxicity. ChemicoBiological Interactions, 156: 131140.

Hamden K, Boujbiha MA, Masmoudi H, Ayadi FM, Jamoussi K, Elfeki A (2009): Combined vitamins (C and $\mathrm{E})$ and insulin improve oxidative stress and pancreatic and hepatic injury in alloxan diabetic rats. Biomedicine \& Pharmacotherapy, 63: 95-99.

Hamilton IMJ, Gilmore WS, Benzie IFF, Mulholland CW, Strain JJ (2000): Interactions between vitamin $\mathrm{C}$ and $\mathrm{E}$ in human subjects. British Journal of Nutrition, 84: 261-267.

Hemila H (1997): Vitamin C intake and susceptibility to pneumonia. The Pediatric Infectious Disease Journal, 16: 836-7.

Hfaiedh N, Murat JC, Elfeki A (2012): A combination of ascorbic acid and $\alpha$-tocopherol or a combination of $\mathrm{Mg}$ and $\mathrm{Zn}$ are both able to reduce the adverse effects of Lindane-poisoning on rat brain and liver. The Journal of Trace Elements in Medicine and Biolog y, 26: 273-278.

Khaldoun-Oularbi H, Richeval C, Djenas N, Lhermitte M, Humbert L, Baz A (2013): Effect of subacute exposure to, abamectin (insecticide) on liver rats (Rattus norvegicus). Annales de toxicologie analytique, 25:63-70.

Kojo S (2004): Vitamin C: basic metabolism and its function as an index of oxidative stress. Current Medicinal Chemistry, 11: 10411064.

Leonard PJ, Persaud J, Motwani R (1971): The estimation of plasma albumin by BCG RCG binding on the Technicon SMA 12/60 ana- lyzer and a comparison with the HABA dye binding technique. Clinica Chimica Acta, 35:409-412.

Marklund S, Marklund G (1974): Involvement of the superoxide anion radical in the autoxidation of pyrogallol and a convenient assay for superoxide dismutase.

The European Journal of Biochemistry, 47:469-474.

Martı'nez-A'lvarez RM, Morales AE, Sanz A (2005): Antioxidant Defenses in Fish: Biotic and Abiotic factors. Reviews in Fish Biology and Fisheries, 15: 75-88.

Matthay MA, Aldrich JM, Gotts JE (2020): Treatment for severe acute respiratory distress syndrome from COVID-19. The Lancet Respiratory Medicine, 8(5): 433434.

Meligi NM, Hassan HF, Honyda SM (2019): Coragen induced toxicity and the ameliorative effect of an Origanum majorana L. in male albino Rats. The Journal of American Science, 15(9):33-44.

Monteiro HR, Pestana JLT, Novais SC, Soares AMVM, Lemos MFL 
(2019): Toxicity of the insecticides spinosad and indoxacarb to the non-target aquatic midge Chironomus riparius. Science of the Total Environment, 666: 1283-1291.

Mossa AH, Refaie AA, Ramadan A (2011): Effect of exposure to mixture of four organophosphate insecticides at No observed adverse effect level dose on rat liver: the protective role of vitamin $\mathrm{C}$. Research Journal of Environmental Toxicology, 5(6) :323-335.

Mousavi SM, Djafarian K, Mojtahed A, Varkaneh HK, Shab-Bidar S (2018): The effect of zinc supplementation on plasma Creactive protein concentrations: $\mathrm{A}$ systematic review and metaanalysis of randomized controlled trials. The European Journal of Pharmacology, 834: 10-16.

Mudaraddi TY, Potadar RR, Kaliwal BB (2012): Indoxacarb induces liver oxidative stress in Swiss Albino Mice. European Journal of Experimental Biology, 2 (1):180186.

Mullan BA, Young IS, Fee H, McCance DR (2002): Ascorbic acid reduces blood pressure and arterial stiffness in type 2 diabetes. Hypertension, 40: 804-809.

Ohkawa H, Ohishi N, Yagi K (1979): Assay for lipid peroxides in animal tissues by thiobarbituric acid reaction. Analytical Biochemistry, 95:351-358.

Paglia DE, Valentine WN (1967): Studies on the quantitative and qualitative characterization of erythrocyte glutathione peroxidse. The Journal of Laboratory and Clinical Medicine, 70:158169.

Paolisso G, Balbi C, Volpe C, Varricchio G, Gambardella A, Saccomanno $\mathrm{F}$, Ammendola S, Varricchio $\mathrm{M}$,
D'Onofrio F (1995): Metabolic benefits deriving from chronic vitamin $\mathrm{C}$ supplementation in aged non-insulin dependent diabetics. The Journal of the American College of Nutrition, 14: 387-92.

Patton CJ, Crouch SR (1977): Spectrophotometric and kinetics investigation of the Berthelot reaction for the determination of ammonia. Analytical Chemistry, 49: 464-469.

Ponda MP, Hostetter TH (2006): Aldosterone Antagonism in Chronic Kidney Disease. The Clinical Journal of the American Society of Nephrology, 1: 668677.

Powell SR (2000): The antioxidant properties of zinc. The Journal of Nutrition, 130: 1447S-54S.

Prasad AS, Beck FW, Endre L, Handschu W, Kukuruga M., Kumar, G (1996): Zinc deficiency affects cell cycle and deoxythymidine kinase gene expression in HUT78 cells. Journal of Laboratory and Clinical Medicine, 128: 5160.

Refaie AAER, Ramadan A, Mossa ATH (2014): Oxidative damage and nephrotoxicity induced by prallethrin in rat and the protective effect of essential oil. Asian Pacific Journal of Tropical Medicine, 7: S506-S513.

Sandeep K, Mukhopadhyay CS, Arora JS, Sethi RS (2016): Indoxacarb interaction alters immunotoxic and genotoxic potential of endotoxin. Journal of Pesticide Science, 41(3): 65-70.

Sandstead HH, Frederickson CJ, Penland JG (2000): History of zinc as related to brain function. The Journal of Nutrition, 130:496S- 502S.

Schaefer TJ, Wolford RW (2005): Disorders of potassium. 
Emergency Medicine Clinics of North America, 23: 723-747.

Shakoori AR, Ali SS, Saleem MA (1988):

Effects of six months feeding of cypermethrin on the blood and liver of albino rats. Journal of Biochemical Toxicology, 3:59-72.

Sutton JL, Basu TK, Dickerson JW (1983): Effect of large doses of ascorbic acid in man on some nitrogenous components of urine. Human nutrition. Applied nutrition, 37:136-140.

Thabrew MI, Joice PD, Rajatissa, W (1987): A Comparative study of the efficacy of Pavetta indica and Osbeckia octandra in the treatment of liver dysfunction. Planta Medica, 53:239-241.

Uchendu C, Ambali SF, Ayo JO (2012): The organophosphate, chlorpyrifos, oxidative stress and the role of some antioxidants: A review. African Journal of Agricultural Research, 7(18): 2720-2728.

US EPA (2000): Pesticide fact sheet: Indoxacarb. U.S. EPA, Washington, DC.

Veeraiah K, Srinivas Rao P, Symyuktha Rani A, Dhilleswarao H (2013): Changes in Biochemical
Parameters of Fresh Water Fish Labeo Rohita Exposed to Lethal And Sub-Lethal Concentrations Of Indoxcarb. International Journal of Bioassays, 2 (10): 1382-1387.

Walmsley RN, White GH (1994): A Guide to Diagnostic Clinical Chemistry. 3rd ed., Blackwell Publication, London, UK. 543 pp.

Wang LS, Wang YR, Ye DW, Liu QQ (2020): A review of the 2019 Novel Coronavirus (COVID-19) based on current evidence. The International Journal of Antimicrobial Agents, 105948.

Young DS, Friedman RB (2001): Effects of disease on clinical laboratory tests, vol 1 and 2, 4th edn. AACC Press, Washington, DC.

Zago MP, Oteiza PI (2001): The antioxidant properties of zinc: interactions with iron and antioxidants. Free Radical Biology and Medicine, 31:266274.

Zhang L, Liu Y. (2020): Potential interventions for novel coronavirus in China: A systematic review. Journal of Medical Virology, 92(5):479-490. 


\title{
ARABIC SUMMARY
}

\section{السُمية الناتجة عن تعرض ذكور الجرذان البيضاء الى الأندوكساكارب

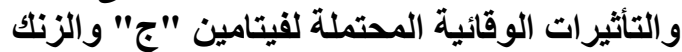

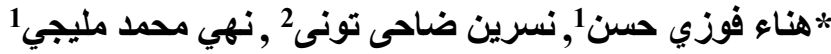

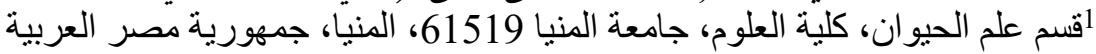

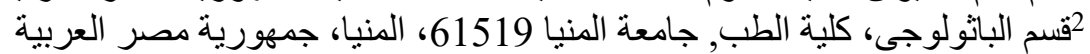

يمكن أن يكون للتعرض بشكل غير مباشر أو الإفراط في التعرض لمبيدة التبدات الآفات عو اقب وخيمة.

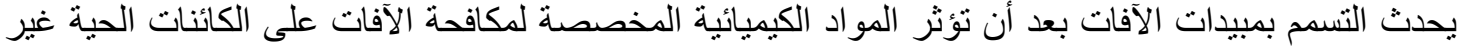

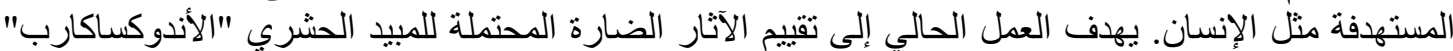

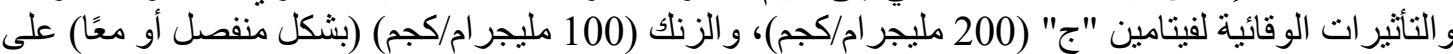

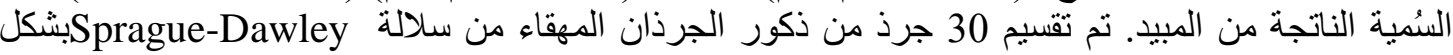

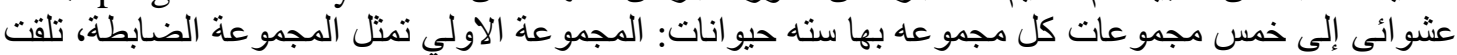

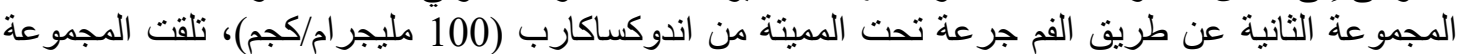

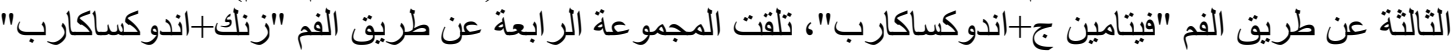

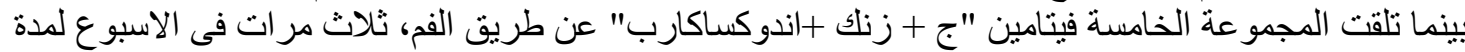

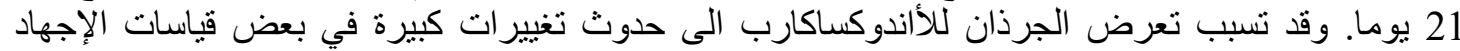

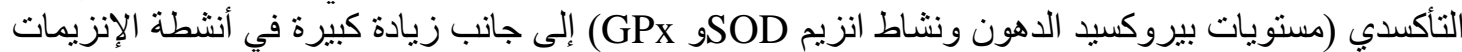

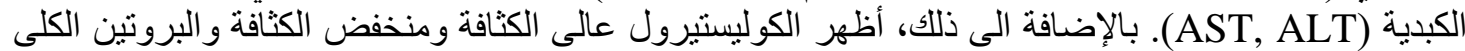

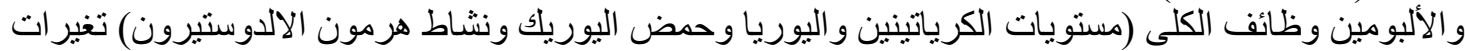

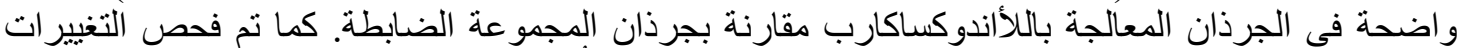

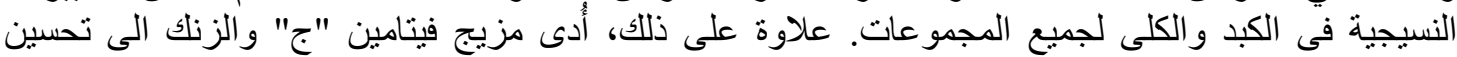

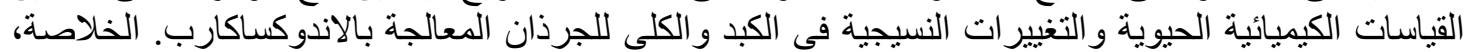

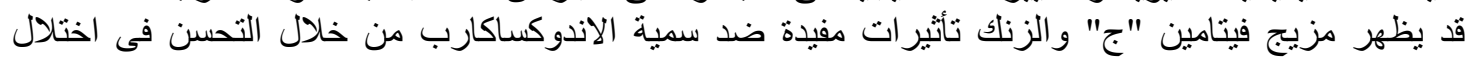
القياسات الكيميائية الحيوية التى تم فحصها و التغييرات النسيجية النية فئ الكبد و الكلى على استخدام أي منهما بمفرده. 